\title{
Paleomagnetism and Tectonic Significance of Albian and Cenomanian Turbidites, Ochoco Basin, Mitchell Inlier, Central Oregon
}

Bernard A. Housen

Western Washington University, bernard.housen@wwu.edu

Rebecca J.Dorsey

Follow this and additional works at: https://cedar.wwu.edu/geology_facpubs

Part of the Geology Commons

\section{Recommended Citation}

Housen, Bernard A. and Dorsey, Rebecca J., "Paleomagnetism and Tectonic Significance of Albian and Cenomanian Turbidites, Ochoco Basin, Mitchell Inlier, Central Oregon" (2005). Geology Faculty Publications. 12.

https://cedar.wwu.edu/geology_facpubs/12 


\title{
Paleomagnetism and tectonic significance of Albian and Cenomanian turbidites, Ochoco Basin, Mitchell Inlier, central Oregon
}

\author{
Bernard A. Housen \\ Geology Department, Western Washington University, Bellingham, Washington, USA
}

Rebecca J. Dorsey

Department of Geological Sciences, University of Oregon, Eugene, Oregon, USA

Received 30 September 2004; revised 11 March 2005; accepted 27 April 2005; published 30 July 2005.

[1] Understanding continental growth and convergent margin dynamics associated with terrane accretion and modification of the Cordilleran margin of North America is prevented by conflicts in paleogeographic models for major terranes, oceanic plates, and the North American margin. We present new paleomagnetic data suggesting that the Blue Mountains superterrane, located at an inboard portion of the Cordilleran margin, has undergone substantial northward translation and clockwise rotation relative to North America since mid-Cretaceous time. Positive baked-contact, conglomerate, and fold tests, provide evidence that the magnetization of these rocks dates from their deposition. These results yield a mean direction of $D=10.8^{\circ}, I=58.5^{\circ}, k=127, \alpha_{95}=4.1^{\circ}$, and $N=11$. Comparison of magnetic inclinations and magnetic fabrics shows no evidence for inclination error. A paleolatitude of $39.2^{\circ}+4.8^{\circ} /-4.3^{\circ} \mathrm{N}$ is obtained, indicating a paleolatitude anomaly of $15.9^{\circ} \pm 4.1^{\circ}$ (northward translation of $1760 \pm 460 \mathrm{~km}$ ) and CW rotation of $37^{\circ} \pm 7.3^{\circ}$ with respect to North America since circa 93 Ma. Application of an ad hoc $5^{\circ}$ inclination error yields translation of $1200 \pm 460 \mathrm{~km}$. Through comparison with other units in the western Cordillera we infer that the Mitchell Inlier was located adjacent to the Sierra Nevada arc during mid-Cretaceous time and that the Blue Mountains province may correlate with the Intermontane superterrane in British Columbia. Other interpretations, such as large inclination errors or an independent displacement history for the Mitchell Inlier, are possible but unlikely. More work is needed to fully test these hypotheses and resolve major questions of Cordilleran tectonics.

Citation: Housen, B. A., and R. J. Dorsey (2005), Paleomagnetism and tectonic significance of Albian and Cenomanian turbidites, Ochoco Basin, Mitchell Inlier, central Oregon, J. Geophys. Res., 110, B07102, doi:10.1029/2004JB003458.

\section{Introduction}

[2] The western Cordillera of North America has long been recognized as a collage of accreted terranes with a complex history of Paleozoic to Mesozoic subduction, magmatism, accretion, and deformation related to convergent and strike-slip relative plate motions [Beck, 1976; Jones et al., 1977; Coney et al., 1980; Monger et al., 1982; Silberling et al., 1984; Engebretson et al., 1985; Burchfiel et al., 1992; Irving et al., 1996; Maxson and Tikoff, 1996; Moores, 1998]. Accurate reconstructions of Cretaceous paleogeography for these terranes are required to understand how the North American continent grew as oceanic crustal fragments accreted to its western margin. While the significance of paleogeographic reconstructions is widely acknowledged, large uncertainties and ongoing debate presently limit our ability to interpret the tectonic

Copyright 2005 by the American Geophysical Union. 0148-0227/05/2004JB003458\$09.00 architecture and evolution of the Cordilleran system. Structural studies and syntheses have documented strong transpressive strain and deformation patterns in regional fault zones such as the Coast shear zone and Western Idaho shear zone that are consistent with large-scale dextral translation of Cordilleran terranes [e.g., Cowan et al., 1997; Fossen and Tikoff, 1998; Andronicos et al., 1999; McClelland et al., 2000; Wyld and Wright, 2001], but the magnitude of translation associated with this deformation can only be constrained with reliable paleogeographic data.

[3] Especially controversial is the magnitude of northward tectonic translation of outboard terranes along the Cordilleran margin during Late Cretaceous and Early Tertiary time. Studies based on geologic correlations and provenance indicators typically suggest either little latitudinal translation of major terranes [e.g., Price and Charmichael, 1986; Mustard et al., 1995; Mahoney et al., 1999; Schott and Johnson, 2001; Dickinson, 2004; Schott et al., 2004], or, in recently proposed models "moderate" latitudinal translation of up to $1000-1500 \mathrm{~km}$ for selected 
terranes [Butler et al., 2001; Umhoefer, 2003; Umhoefer and Blakey, 2005; Wyld et al., 2005]. In contrast paleomagnetic studies yielding anomalously shallow magnetic inclinations are indicative of large (approximately 2000$3500 \mathrm{~km}$ ) northward terrane translation [e.g., Beck, 1976; Beck et al., 1981; Irving et al., 1995; Johnston et al., 1996; Wynne et al., 1995; Irving et al., 1996; Wynne et al., 1998; Enkin et al., 2001, 2003; Housen et al., 2003; Bogue and Grommé, 2004; Kim and Kodama, 2004]. Some studies based on geologic data such as paleoflora temperature reconstructions [Miller et al., 2003] and interpretations of detrital zircon ages [Housen and Beck, 1999] are also consistent with the large-translation models.

[4] The Blue Mountains province of eastern Oregon occupies an important but poorly understood position in the paleogeography of the North American Cordillera. The province contains a complex of accreted Paleozoic and Mesozoic arc and subduction-mélange terranes that are juxtaposed against the Cretaceous Idaho Batholith along the Salmon River suture zone (Figure 1) [Dickinson and Thayer, 1978; Lund and Snee, 1988; Selverstone et al., 1992; Avé Lallemant, 1995; McClelland et al., 2000]. Its isolated geographic position and anomalous location east of similar terranes to the north and south have lead to conflicting correlations with other major units in the Cordilleran system. Some have suggested that the Wallowa terrane (Seven Devils arc) in the Blue Mountains correlates with Wrangellia in western British Columbia [e.g., Jones et al., 1977; Hillhouse et al., 1982; Wernicke and Klepacki, 1988; Dickinson, 2004]. Others have presented data that support correlation of the Wallowa terrane to the Stikinia arc terrane, a part of the Intermontane superterrane [e.g., Sarewitz, 1983; Mortimer, 1986]. Although different hypotheses exist for the history of amalgamation and accretion of the Blue Mountains terranes to North America [Brooks and Vallier, 1978; Dickinson and Thayer, 1978; Dickinson, 1979; Wernicke and Klepacki, 1988; Follo, 1992; White et al., 1992; Avé Lallemant, 1995], all of them place the Blue Mountains at about their present location with respect to North America by Middle Jurassic or Early Cretaceous time [e.g., Cowan et al., 1997; Dickinson, 2004]. Wyld and Wright [2001] proposed that Triassic-Jurassic volcanic and sedimentary rocks in the Blue Mountains correlate with similar rocks in the Black Rock desert of western Nevada, and that the Blue Mountains were translated approximately $400 \mathrm{~km}$ north to their present position by mid-Cretaceous time. This reconstruction, which appears to place an upper limit on northward displacement of the Blue Mountains terranes, has not been tested in previous paleomagnetic studies.

[5] This paper presents the results of a paleomagnetic study of mid Cretaceous (Albian to Cenomanian) sedimentary rocks that depositionally overlie low-grade metamorphic rocks of the Blue Mountains superterrane in the Mitchell Inlier, central Oregon (Figure 1). These results are the first published paleomagnetic data from sedimentary rocks of this age in the Blue Mountains and thus provide new constraints on the paleogeography of this region for an important period in Cordilleran tectonics. The results also allow us to evaluate tectonic reconstructions that are based on evidence for large post-Cretaceous CW rotations [e.g.,
Dickinson and Thayer, 1978; Wyld and Wright, 2001; Dickinson, 2002].

\section{Previous Paleomagnetic Studies}

[6] Paleomagnetic studies provide critical constraints on paleogeography because they yield an absolute paleolatitude via the geocentric axial dipole (GAD) hypothesis. This approach permits robust statistical comparisons between different data sets and tests to check for possible systematic errors in the paleomagnetic data, such as inclination error in sedimentary rocks. For example, paleolatitudes obtained by paleomagnetic studies of hematite-bearing sedimentary rocks from central Asia indicate latitudinal translation far in excess of that predicted from geologic and tectonic observations [e.g., Gilder et al., 2001]. By examining the relation between mineral alignment and inclination [Dupont-Nivet et al., 2002], statistically different inclinations in coeval red beds and basalts [Gilder et al., 2003], and the shape-distribution of the paleomagnetic directions themselves [Tauxe and Kent, 2004], it has been demonstrated that the inclination recorded by detrital hematite in rocks from central Asia is subject to a large inclination error of $10^{\circ}$ to $20^{\circ}$.

\subsection{North America Cordilleran Terranes}

[7] As in the case with the central Asia paleomagnetic inclination anomalies, conflicting paleogeographic reconstructions of Cordilleran terranes in western North America have resulted in healthy scrutiny of both the geologic and paleomagnetic evidence on which they are based. Unrecognized tilt, deformation, or variations in magnetization age of plutonic rocks may play a role in some anomalous shallow inclinations [Butler et al., 1989; Brown and Burmester, 1991; Butler et al., 2001; 2002; Hollister et al., 2004], but these sources of error have been ruled out or corrected for in other studies [Irving and Archibald, 1990; Ague and Brandon, 1996; Housen et al., 2003]. Some sedimentary and volcanic units have been demonstrably remagnetized, and thus do not provide reliable information about paleolatitude [Bogue et al., 1989; Bazard et al., 1990; Burmester et al., 1990, 2000; Enkin et al., 2002]. In other cases, positive paleomagnetic field tests have shown that stratified units have magnetizations that date from their formation, and therefore provide solid constraints on paleolatitude [e.g., Irving et al., 1995; Wynne et al., 1995; Enkin et al., 2001; Stamatakos et al., 2001; Enkin et al., 2003; Haskin et al., 2003; Bogue and Grommé, 2004].

[8] Butler et al. [2001] argued that all paleolatitude anomalies obtained from paleomagnetic studies of Cretaceous rocks of the North American Cordillera that have post-Cretaceous translation estimates in excess of $1000 \mathrm{~km}$ can be explained by the combined effects of pluton tilt, inclination error, and complex deformation. This conclusion has become widely accepted in the tectonics community [e.g., Dickinson, 2004] despite a set of robust paleomagnetic studies with detailed evaluation of the above effects that indicates larger latitudinal discrepancies. Such studies suggest $3000 \mathrm{~km}$ of latitudinal translations for the Insular superterrane since 91-87 Ma [Wynne et al., 1995; Enkin et al., 2003; Housen et al., 2003; Bogue and Grommé, 2004] and lesser translations of 1600 to $2200 \mathrm{~km}$ since 


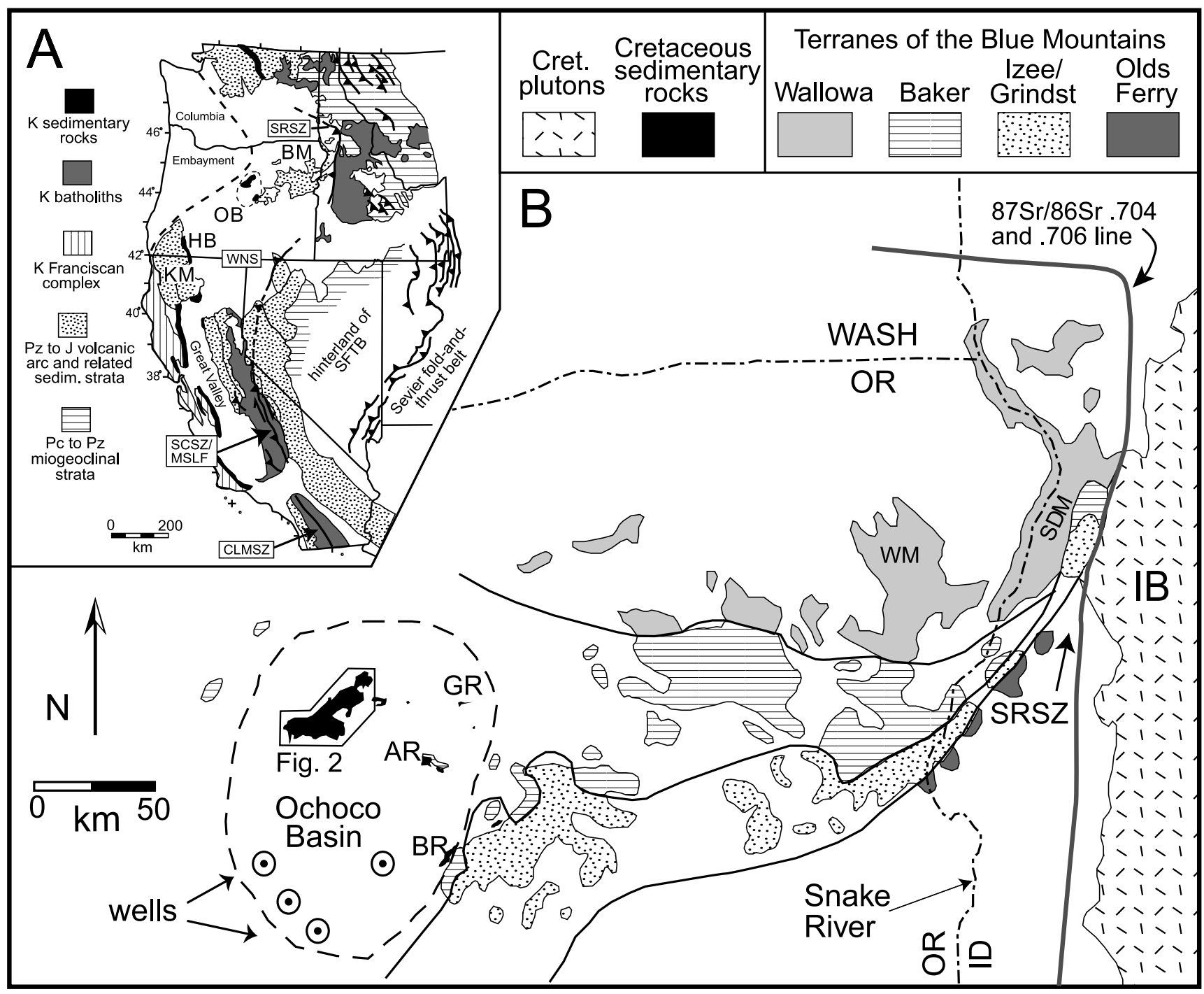

Figure 1. Regional tectonic setting of the Ochoco basin. (a) Simplified pre-Tertiary geology of the western United States, modified from Wyld and Wright [2001]. Dashed line through Oregon and Washington defines Columbia embayment and follows approximate trend of fabrics in accreted terranes of the Blue Mountains and Klamath Mountains. Line for SRSZ coincides with ${ }^{87} \mathrm{Sr} /{ }^{86} \mathrm{Sr}$ isotope boundary of Armstrong et al. [1977; and Figure 1b]. (b) Distribution of accreted terranes in central and eastern Oregon, which together make up the Blue Mountains superterrane. Black areas indicate Cretaceous strata of the Ochoco basin; circled dots show location of subsurface wells [Thompson et al., 1984]. Modified from Dickinson [1979]. Approximate extent of Ochoco basin is indicated with dashed line in Figures 1a and 1b. AR, Antone Ranch; BM, Blue Mountains; BR, Bernard Ranch; CLMSZ, Cuyamaca-Laguna Mountains shear zone; GR, Goose Rock; HB, Hornbrook Basin; IB, Idaho Batholith; J, Jurassic; KM, Klamath Mountains; MSLF, Mojave-Snow Lake Fault; MZ, Mesozoic; OB, Ochoco Basin; Pc, Precambrian; Pz, Paleozoic; SCSZ, Sierra Crest Shear Zone System; SDM, Seven Devils Mountains; SFTB, Sevier Fold and Thrust Belt; SRSZ, Salmon River Suture; WM, Wallowa Mountains; WNS, Western Nevada Shear Zone.

about 80 Ma [Enkin et al., 2001; Stamatakos et al., 2001; Kim and Kodama, 2004]. The Intermontane superterrane contains paleomagnetic evidence for translations of $1100-$ $1400 \mathrm{~km}$ since $105 \mathrm{Ma}$ [e.g., Irving et al., 1995; Haskin et al., 2003]. Paleomagnetic results show that Cretaceous rocks of the Omineca Belt, located inboard of the Intermontane superterrane, have experienced no significant postCretaceous latitudinal translation [Irving and Archibald, 1990]. In light of unresolved contradictions between the above studies and the conclusions of Butler et al. [2001], there presently is no consensus on the paleogeography, paleolatitude, and history terrane translations in the North American Cordillera.

\subsection{Blue Mountains Paleomagnetism}

[9] Previous paleomagnetic research in the Blue Mountains has focused on two tectonic questions. The first concerns the paleogeography of Triassic volcanic and vol- 
- Paleomagnetism Site

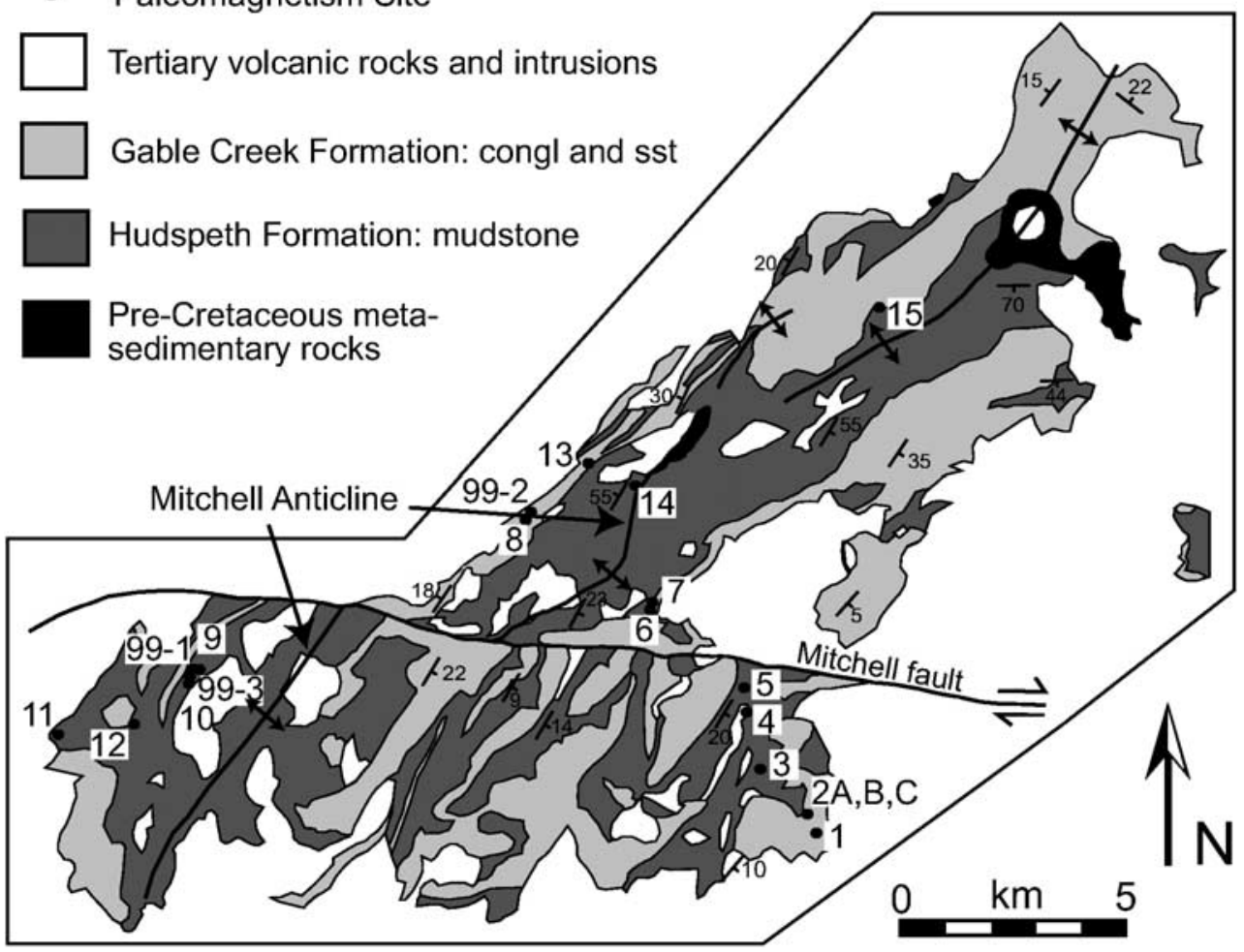

Figure 2. Simplified geologic map of the Mitchell Inlier showing distribution of the Hudspeth and Gable Creek formations, NE trending Mitchell anticline, and other geologic features (modified from Kleinhans et al. [1984] with original map from Oles and Enlows [1971]). Paleomagnetic sampling sites are shown as solid dots.

caniclastic rocks of the Wallowa and Olds Ferry terranes (Seven Devils and Huntington arcs), and their possible correlation to Wrangellia [Hillhouse et al., 1982; see also Dickinson, 2004]. Paleomagnetic data from Triassic rocks [Hillhouse et al., 1982] indicate that during Triassic time the Wallowa and Olds Ferry terranes were at paleolatitudes similar to those of Wrangellia (Insular superterrane) [Hillhouse and Grommé, 1984; Yole and Irving, 1980], and that large vertical axis rotations of these rocks have occurred.

[10] The second question concerns the history of vertical axis oroclinal rotation of the Blue Mountains as originally proposed for the Columbia Embayment [Hamilton and Myers, 1966]. Wilson and Cox [1980] concluded that the Blue Mountains have undergone $60^{\circ}$ of $\mathrm{CW}$ rotation and no significant latitudinal displacement of the Blue Mountains relative to North America since early Cretaceous time. The rotation estimate provided by Wilson and Cox [1980] is consistent with the oroclinal rotation of the Blue Mountains to form the Columbia Embayment and has been widely utilized in a number of tectonic reconstructions [Dickinson and Thayer, 1978; Hillhouse et al., 1982; Wernicke and Klepacki, 1988; Wyld and Wright, 2001; Dickinson, 2002], even though the rotation estimate has significant uncertainty due to lack of paleohorizontal control and the small number of sites. A more robust indicator of rotation, in younger rocks, is provided by paleomagnetic data from more than 40 sites in the Eocene Clarno volcanics compiled by Grommé et al. [1986]. They found that the portion of the Blue Mountains overlain by the Clarno Volcanics has a paleolatitude consistent with that expected for their present location in North America, and that $16^{\circ} \pm 10^{\circ}$ of $\mathrm{CW}$ rotation has occurred since Eocene time. This rotation was attributed to extensional tectonics in the northern Basin and Range province.

\section{Geology of the Mitchell Inlier}

[11] The Mitchell Inlier is a surface exposure of Cretaceous sedimentary rocks of the larger Ochoco Basin in east central Oregon (Figures 1 and 2). These rocks have been divided into two conformable and interbedded lithologies, the Hudspeth Formation (primarily fine-grained turbiditic mudstone and siltstone) and the Gable Creek Formation (primarily fine- to coarse-grained sandstone with some intraformational conglomerate and sedimentary breccias) [Wilkinson and Oles, 1968; Oles and Enlows, 1971]. Both formations contain submarine slope and fan deposits. The age of the sediments is known from ammonite biostratigraphy, which shows that the Main Mudstone member of the Hudspeth Formation is Albian and the overlying Gable Creek Formation, though lacking good fossil control, is Cenomanian based on its conformable interfingering contact with the Hudspeth Formation [McKnight, 1964; Wilkinson and Oles, 1968; Kleinhans et al., 1984; P. Rodda, personal communication, 2000]. Some workers have suggested that the rocks of the Ochoco Basin are correlative to similarly aged sedimentary rocks of the Hornbrook Formation in the Klamath Mountains, southwestern Oregon [Kleinhans et al., 1984; Nilsen, 1986]. Andesitic volcanic and volcaniclastic rocks of the Eocene Clarno Formation 
Table 1. Paleomagnetic Sites and Site Mean Data

\begin{tabular}{|c|c|c|c|c|c|c|c|c|c|c|}
\hline Site & $\begin{array}{c}\text { Latitude, } \\
{ }^{\circ} \mathrm{N}\end{array}$ & $\begin{array}{l}\text { Longitude, } \\
{ }^{\circ} \mathrm{W}\end{array}$ & $\mathrm{N} / \mathrm{No}$ & $D$ & $I$ & $k$ & $\alpha_{95}$ & $\begin{array}{c}\text { Bed } \\
\mathrm{s} / \mathrm{d}\end{array}$ & $\mathrm{Fm}$ & Position \\
\hline 99Km1 & $44^{\circ} 33.405^{\prime}$ & $120^{\circ} 19.070^{\prime}$ & $4 / 4$ & 316.0 & 60.8 & 60.6 & 11.9 & $336 / 36$ & $\mathrm{H}$ & $\mathrm{S}$ \\
\hline $99 \mathrm{Km} 2$ & $44^{\circ} 35.645^{\prime}$ & $120^{\circ} 12.748^{\prime}$ & $5 / 5$ & 34.8 & 60.1 & 96.1 & 7.8 & $218 / 32$ & $\mathrm{H}$ & $\mathrm{N}$ \\
\hline $99 \mathrm{Km} 3$ & $44^{\circ} 33.405^{\prime}$ & $120^{\circ} 19.070^{\prime}$ & $0 / 3$ & - & - & - & - & $202 / 51$ & $\mathrm{H}$ & $\mathrm{S}$ \\
\hline $00 \mathrm{Km} 1$ & $44^{\circ} 31.578^{\prime}$ & $120^{\circ} 6.954^{\prime}$ & $9 / 10$ & 1.8 & 55.0 & 24.1 & 10.7 & $052 / 09$ & $\mathrm{GC}$ & $\mathrm{S}$ \\
\hline $00 \mathrm{Km} 2 \mathrm{a}$ & $44^{\circ} 31.714^{\prime}$ & $120^{\circ} 7.257^{\prime}$ & $5 / 6$ & 355.5 & 63.0 & 47.4 & 11.2 & $349 / 06$ & $\mathrm{GC}$ & $\mathrm{S}$ \\
\hline $00 \mathrm{Km} 2 \mathrm{~b}$ & $44^{\circ} 31.714^{\prime}$ & $120^{\circ} 7.257^{\prime}$ & $3 / 3$ & 7.1 & 58.9 & 93.8 & 12.8 & $338 / 05$ & $\mathrm{GC}$ & $\mathrm{S}$ \\
\hline $00 \mathrm{Km} 2 \mathrm{c}$ & $44^{\circ} 31.714^{\prime}$ & $120^{\circ} 7.257^{\prime}$ & $6 / 6$ & 28.0 & 65.4 & 27.4 & 13.0 & $235 / 05$ & $\mathrm{GC}$ & $\mathrm{S}$ \\
\hline $00 \mathrm{Km} 3^{\mathrm{b}}$ & $44^{\circ} 32.406^{\prime}$ & $120^{\circ} 8.025^{\prime}$ & $2 / 3$ & 1.8 & 66.1 & 18.8 & 40 & $008 / 10$ & $\mathrm{H}, \mathrm{C}$ & $\mathrm{S}$ \\
\hline $00 \mathrm{Km} 4$ & $44^{\circ} 33.118^{\prime}$ & $120^{\circ} 8.217^{\prime}$ & $7 / 15$ & 11.9 & 56.0 & 22.6 & 13.0 & $275 / 09$ & GC & $\mathrm{S}$ \\
\hline $00 \mathrm{Km} 5$ & $44^{\circ} 33.363^{\prime}$ & $120^{\circ} 8.432^{\prime}$ & $5 / 5$ & 45.4 & 72.0 & 20.8 & 17.2 & $270 / 15$ & $\mathrm{H}$ & $\mathrm{S}$ \\
\hline $00 \mathrm{Km} 6$ & $44^{\circ} 34.165^{\prime}$ & $120^{\circ} 10.006^{\prime}$ & $6 / 8$ & 335.2 & 67.1 & 40.8 & 10.6 & $014 / 26$ & $\mathrm{GC}$ & $\mathrm{N}$ \\
\hline $00 \mathrm{Km} 7$ & $44^{\circ} 34.166^{\prime}$ & $120^{\circ} 10.007^{\prime}$ & $6 / 6$ & 339.6 & 61.4 & 131.0 & 5.9 & $008 / 29$ & $\mathrm{GC}$ & $\mathrm{N}$ \\
\hline $00 \mathrm{Km} 8$ & $44^{\circ} 35.645^{\prime}$ & $120^{\circ} 12.748^{\prime}$ & $8 / 16$ & 38.2 & 60.0 & 87.1 & 6.0 & $214 / 29$ & $\mathrm{H}$ & $\mathrm{N}$ \\
\hline $00 \mathrm{Km} 9$ & $44^{\circ} 33.405^{\prime}$ & $120^{\circ} 19.070^{\prime}$ & $14 / 14$ & 58.4 & 47.4 & 75.8 & 4.6 & $196 / 40$ & $\mathrm{H}$ & $\mathrm{S}$ \\
\hline $00 \mathrm{Km} 10$ & $44^{\circ} 33.405^{\prime}$ & $120^{\circ} 19.070^{\prime}$ & $4 / 4$ & 59.3 & 52.4 & 117.2 & 8.5 & $203 / 43$ & $\mathrm{H}$ & $\mathrm{S}$ \\
\hline $00 \mathrm{Km} 11^{\mathrm{c}}$ & $44^{\circ} 32.954^{\prime}$ & $120^{\circ} 21.166^{\prime}$ & $10 / 11$ & 212.6 & 00.2 & 1.36 & 77.3 & NA & $\mathrm{GC}$ & $\mathrm{S}$ \\
\hline $00 \mathrm{Km} 12$ & $44^{\circ} 33.021^{\prime}$ & $120^{\circ} 19.852^{\prime}$ & $3 / 5$ & 317.1 & 67.9 & 63.0 & 15.7 & $315 / 23$ & $\mathrm{H}$ & $\mathrm{S}$ \\
\hline $00 \mathrm{Km} 13$ & $44^{\circ} 36.351^{\prime}$ & $120^{\circ} 11.374^{\prime}$ & $3 / 4$ & 25.3 & 56.9 & 76.8 & 14.2 & $214 / 41$ & $\mathrm{GC}$ & $\mathrm{N}$ \\
\hline $00 \mathrm{Km} 14$ & $44^{\circ} 36.152^{\prime}$ & $120^{\circ} 10.312^{\prime}$ & $6 / 6$ & 347.0 & 24.6 & 90.3 & 7.1 & $018 / 05$ & $\mathrm{H}$ & $\mathrm{N}$ \\
\hline $00 \mathrm{Km} 15$ & $44^{\circ} 38.155^{\prime}$ & $120^{\circ} 5.010^{\prime}$ & $6 / 6$ & 167.0 & -69.0 & 315.7 & 3.8 & $252 / 30$ & $\mathrm{GC}$ & $\mathrm{N}$ \\
\hline Group mean & $\mathrm{S}$ of fault & in situ & 11 & 14.0 & 64.6 & 20.44 & 10.3 & & & \\
\hline Group mean & $\mathrm{S}$ of fault & tilt corrected & 11 & 10.8 & 58.5 & 127.0 & 4.1 & & & \\
\hline
\end{tabular}

${ }^{a}$ WGS 83 datum. N/No are number of accepted/number of demagnetized samples, $D$ and $I$ are declination and inclination of site mean direction in in situ coordinates, and $k$ and $\alpha_{95}$ are Fisher [1953] statistics for mean directions. Bed s/d is bedding strike/dip. Fm is formation: H, Hudspeth Formation turbidites; GC, Gable Creek Formation sandstone and turbidites. Position refers to position north or south of the Mitchell Fault.

${ }^{\mathrm{b}}$ Baked-contact site results from unbaked samples.

${ }^{\mathrm{c} C}$ Conglomerate test site.

unconformably overlie Cretaceous sedimentary rocks in the Mitchell area [Wilkinson and Oles, 1968; Oles and Enlows, 1971; Grommé et al., 1986].

[12] The structural geology of the Mitchell Inlier is dominated by a set of NE trending folds, the largest of which is the Mitchell anticline (Figure 2) [Oles and Enlows, 1971]. Most folds in this area formed during Tertiary time, based on involvement of the overlying Eocene rocks in these structures. However, detailed structural and sedimentological analysis has documented an episode of Albian syndepositional folding affecting the oldest part of the Cretaceous section at Toney Butte, north of the paleomagnetic sampling area [Lenegan, 2001, R. J. Dorsey and R. L. Lenegan, Structural controls on middle Cretaceous sedimentation in the Toney Butte area, Ochoco basin, central Oregon, in Convergent Margin Terranes and Associated Regions, edited by M. Cloos, submitted to Special Paper of the Geological Society of America, 2005]. The Mitchell Fault is a strike-slip fault that cuts Eocene volcanic rocks and is kinematically associated with Tertiary folding [Wilkinson and Oles, 1968; Oles and Enlows, 1971] (Figure 2).

\section{Sampling and Methods}

[13] For this study, a total of 20 sample sites were visited, with 5 to 20 oriented samples collected at each site (Table 1 and Figure 2). The site locations were recorded using a handheld GPS unit. The samples were either drilled in the field with a gas or electric powered drill, or collected as oriented block samples. The drilled samples were oriented using both magnetic and sun compasses; the declinations of the magnetic and sun compass all agreed to within a degree. Turbidite sites were selected for freshness of exposure and to maximize the use of large-scale folds (such as the Mitchell anticline) for a paleomagnetic fold test. Both sandstone and siltstone beds, and several concretions, were sampled where best exposed. One site $(00 \mathrm{Km} 11)$ was of an intraformational sediment breccia in the Gable Creek Formation. One sample from each of 11 separate angular sandstone blocks was collected from this site in order to perform a conglomerate test. One site $(00 \mathrm{Km} 3)$ was an andesite dike of the Clarno volcanics and the Hudspeth Formation turbidites it baked. Samples of the dike, and a transect of sandstone samples from directly adjacent to the dike to a distance of 15 meters from the dike were collected in order to perform a baked contact test. All samples were cut into standard $2.2 \mathrm{~cm}$ long specimens, and stored in the WWU paleomagnetism laboratory's magnetic field-free room.

[14] The anisotropy of magnetic susceptibility (AMS) of most specimens was measured with an AGICO KLY-3S Kappabridge. For the paleomagnetic work, specimens were subjected to either step-wise alternating field (AF) demagnetization (using a D-Tech D-2000 AF demagnetizer), or to step-wise thermal demagnetization (using an ASC TD-48 thermal demagnetizer). The magnetizations of the samples were measured using a 2-G 755 DC SQUID magnetometer, using an eight-position rotation scheme. Principal component analysis (PCA) [Kirschvink, 1980] was used to determine the directions of magnetization components. A limited number of specimens were also used for magnetic hysteresis analysis, using the Princeton Measurements 3900 VSM at the Institute for Rock Magnetism (IRM).

\section{Results and Interpretation}

\subsection{Paleomagnetism}

[15] Step-wise demagnetization of the specimens revealed two components of magnetization in most of the specimens. The first-removed component was isolated between the 5 

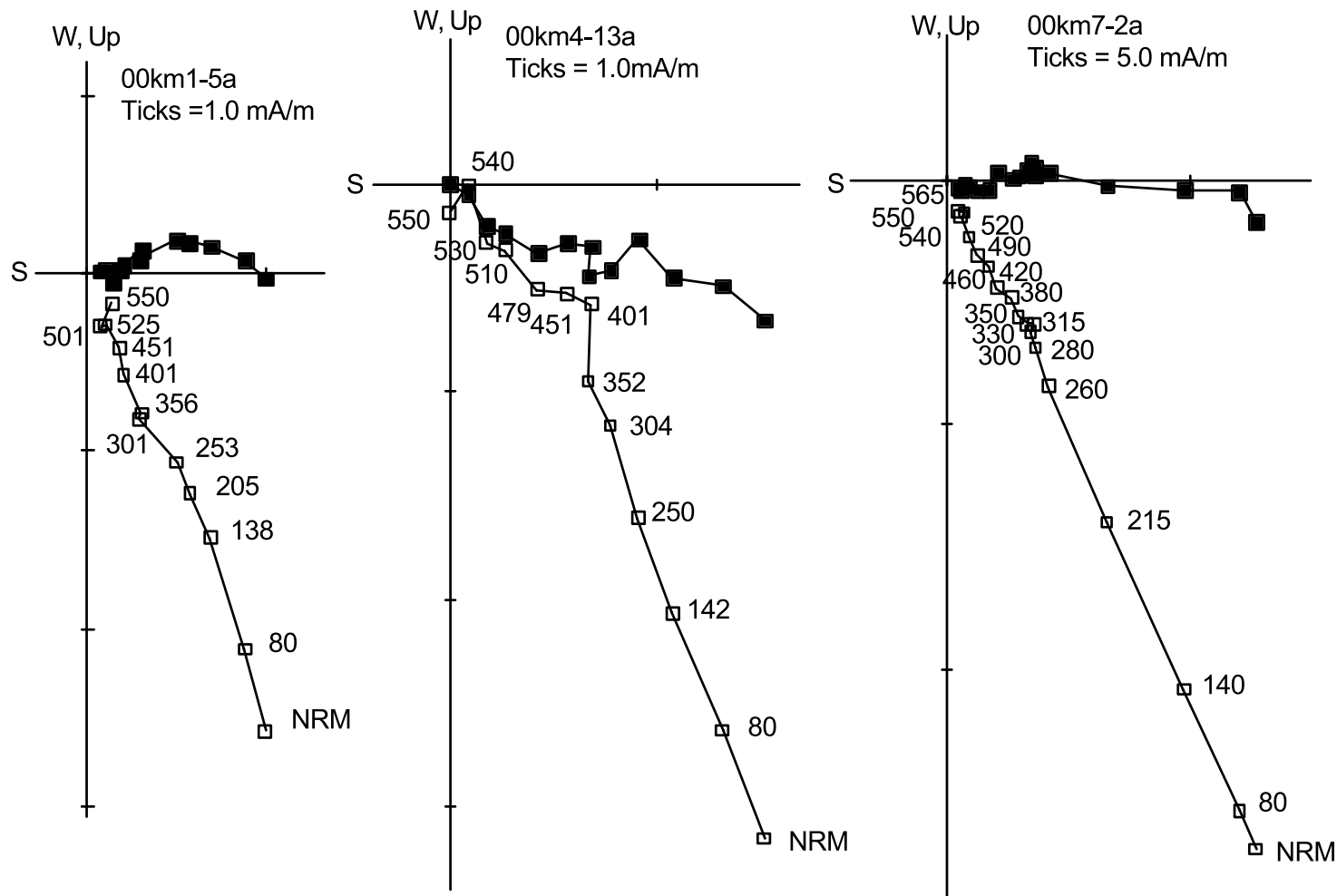

Figure 3. Orthogonal vector plots of demagnetization experiments, depicting results that are typical of this study. Solid symbols denote projection of the horizontal component of the magnetization vector, open symbols denote projection of the vertical component of the magnetization vector. Demagnetization steps $\left({ }^{\circ} \mathrm{C}\right)$ are indicated.

and $30 \mathrm{mT}$ AF demagnetization steps, or between the $70^{\circ}$ and $350^{\circ} \mathrm{C}$ thermal demagnetization steps (Figure 3). This component is always north directed and steeply down. The second-removed component was isolated between the 30 and $120 \mathrm{mT} \mathrm{AF}$ demagnetization steps, and between the $350^{\circ}$ and $580^{\circ} \mathrm{C}$ thermal demagnetization steps (Figure 3). The directions of these magnetization components were accepted if defined by at least 4 demagnetization steps with a maximum angular deviation (MAD) value of $<20^{\circ}$. Using these criteria, 113/140 samples had acceptable magnetization directions. The mean directions of these two components from each site were calculated using Fisher [1953] statistics (Table 1). With the exception of one site $(00 \mathrm{Km} 15)$, the mean directions of the second-removed components for all of the Gable Creek and Hudspeth Formation sites are northerly and moderately downward directed.

[16] The anomalous site $(00 \mathrm{Km} 15)$ is located in the northern portion of the Mitchell Inlier, and is more physically weathered than the others. The oriented block samples produced strikingly orange-brown cuttings when drilled in the lab that differed markedly from the typical grey to tan cuttings from all of the other samples. The directions from $00 \mathrm{Km} 15$ are very well defined (Figure $4 \mathrm{a}$ ), and yield a site mean of $D=167, I=-69, k=315.7, N=6$, and $\alpha_{95}=3.8^{\circ}$, very similar to that of the reverse polarity mean direction from the Eocene Clarno Formation (Figure 4b) reported by Grommé et al. [1986]. We interpret this site to have suffered from an Eocene remagnetization, and will not include its result in any further analyses.

\subsubsection{Baked-Contact Test: Site $00 \mathrm{Km} 3$}

[17] Results from the $0.8 \mathrm{~m}$ wide andesite dike have second-removed components that are steeply up (Figure 5a), and are similar to directions found in a larger study of the paleomagnetism of the Clarno Formation [Grommé et al., 1986]. The baked-contact samples from 5 to $35 \mathrm{~cm}$ from the dike margin have second-removed components that are south and steeply up (Figures $5 \mathrm{~b}$ and $5 \mathrm{c}$ ). Between 35 and $388 \mathrm{~cm}$ from the dike margin, this same southerly and steeply up direction is present, but is removed at lower unblocking temperatures, and a poorly defined, but clearly north and downward directed magnetization component is present (Figure 5d). At distances $>3 \mathrm{~m}$ from the dike margin, the second-removed component is northerly and down (Figure 5e), and resembles the directions found in the turbidites from elsewhere in the study area. We interpret the results of the baked contact test to indicate that well-defined magnetizations of differing ages were obtained from the dike and the baked contact, and the unbaked zone at a distance from the dike (Figure 5f). Moreover, the maximum unblocking temperature of the steeply up magnetization component in the baked rocks decreases as a function of distance from the dike margin, as would be predicted for a partial TRM acquired during a finite heating event. This is a positive baked contact test, indicating the magnetization found in the unbaked turbidites predates the age of the intrusives (in this case, the Eocene [Grommé et al., 1986]).

\subsubsection{Conglomerate Test: Site $00 \mathrm{Km} 11$}

[18] Results from the blocks of sandstone breccia within the Gable Creek Formation have two components of mag- 
a.

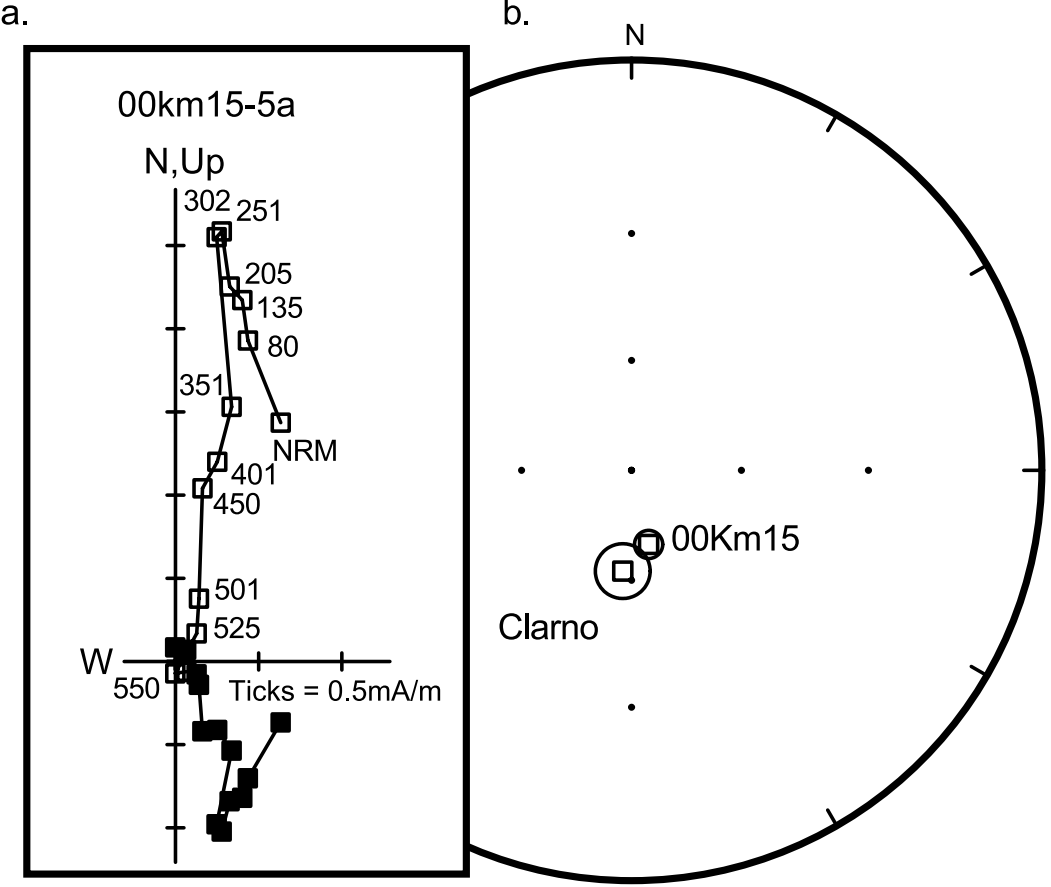

Figure 4. (a) Orthogonal vector plot of typical demagnetization experiment for site $00 \mathrm{Km} 15$. (b) Equalangle projection of the site mean second-removed magnetization component for site $00 \mathrm{Km} 15$, with mean of the reverse-polarity sites of the Eocene Clarno volcanics [Grommé et al., 1986] shown for comparison. Circle is radius of $\alpha_{95}$ for each mean direction.

netization; a first-removed component that is always northerly and down, and a second-removed component that is well defined, but has widely variable directions (Figure 6). The mean direction of the second-removed component for this site has a $\mathrm{k}=1.3(\mathrm{~N}=10)$, which is statistically random. Interestingly, the directions themselves fall mainly along a great circle that is close to the bedding plane of the breccia matrix (Figure 7); this pattern of directions is perhaps due to a nonrandom alignment of the tabular sandstone clasts during deposition of the breccia. Irregardless, this result constitutes a positive conglomerate test for the Gable Creek Formation, indicating its magnetization predates the deposition of the sediment breccia. Because this breccia unit occurs within the upper portion of the Gable Creek Formation itself, the magnetization of the Gable Creek Formation as a whole must have occurred shortly after the sediments were first deposited.

\subsubsection{Paleomagnetic Fold Tests}

[19] The degree to which the clustering of site mean directions varies as a function of structural correction can be evaluated using statistically based fold tests. Using all of the site mean directions together, the Tauxe and Watson [1994] fold test (Figure 8) indicates that the maximum clustering of directions occurs at about $60-70 \%$ untilting, and that the $100 \%$ tilt-corrected result is ruled out at $95 \%$ confidence. This could indicate that, despite the positive conglomerate and baked contact tests, these rocks were all subjected to a synfolding remagnetization event.

[20] Structural complications, including both multiple episodes of folding, and vertical axis rotations between site locations, can also produce a fold test that would indicate an apparent synfolding magnetization [Watson and Enkin, 1993; Tauxe and Watson, 1994; Enkin and Watson, 1996; Enkin, 2003]. For this reason we subdivided our sites into two groups; those sites south of the Mitchell Fault, and those sites north of the Mitchell Fault. Using the parametric version (due to the smaller sample size) of the Tauxe and Watson [1994] fold test, the southern group of sites has a peak in clustering at $85-$ $90 \%$ untilting, with a $95 \%$ confidence interval ranging from 66 to $103 \%$ untilting (Figure 9). Because the 95\% confidence interval includes $100 \%$ untilting, and the baked contact and conglomerate tests were both positive, we conclude that the sites located south of the Mitchell Fault pass the fold test, and that the most appropriate direction to use is that at $100 \%$ untilting. This conclusion is also supported by the D-C fold test of Enkin [2003], which tests for correlations between the dispersion of paleomagnetic directions and the dip directions of bedding in the study area. The result of the D-C fold test for the sites located south of the Mitchell Fault (Figure 10) indicates maximum clustering of directions at $83 \% \pm 18 \%$ (95\% confidence interval) untilting. This also constitutes a positive fold test at $95 \%$ confidence. Comparing the inclinations with $\%$ untilting we find only minor $\left(1.5^{\circ}\right)$ and statistically insignificant differences between the mean inclination at $80-90 \%$ untilting and the mean inclination at $100 \%$ unfolding (Figure 11). Using the $100 \%$ untilting results yields a Fisher mean direction of $D=10.8^{\circ}, I=58.5^{\circ}, k=127, \alpha_{95}=4.1^{\circ}$, and $N=11$ for the sites south of the Mitchell Fault. In order to evaluate any additional complexities, perhaps due to minor vertical axis rotation, we also used inclination-only statistics [McFadden and Reid, 1982] to calculate the 
a.

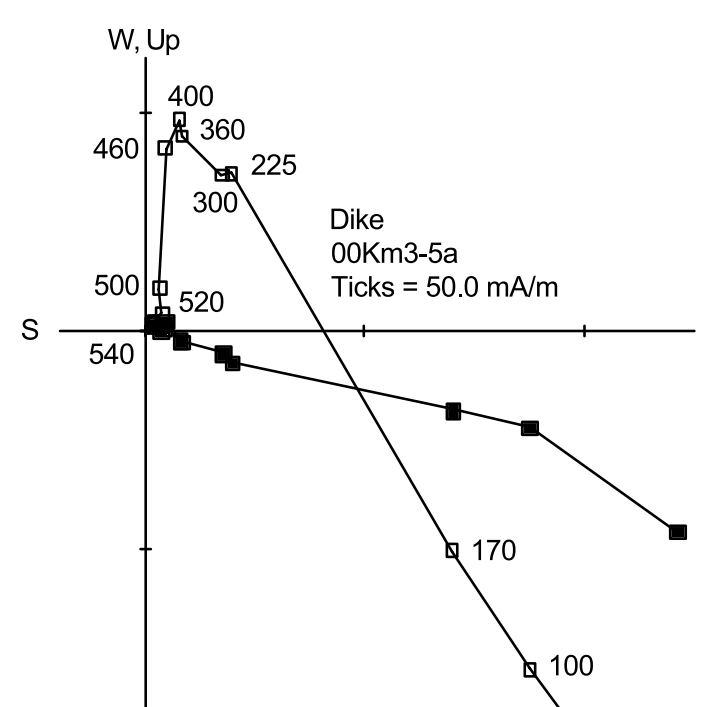

b.

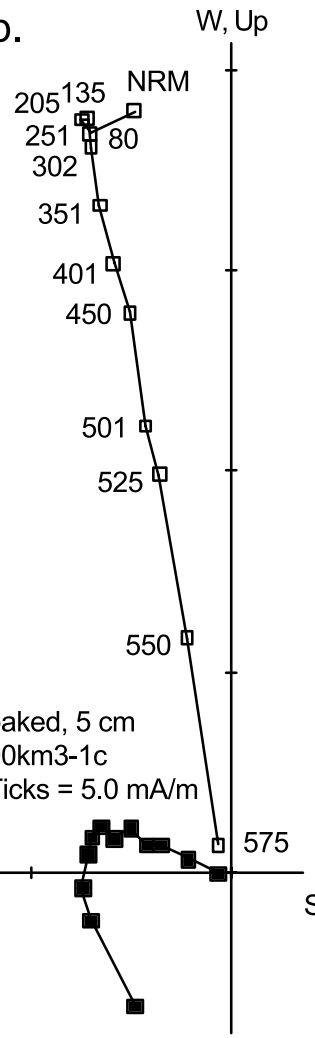

575

c.

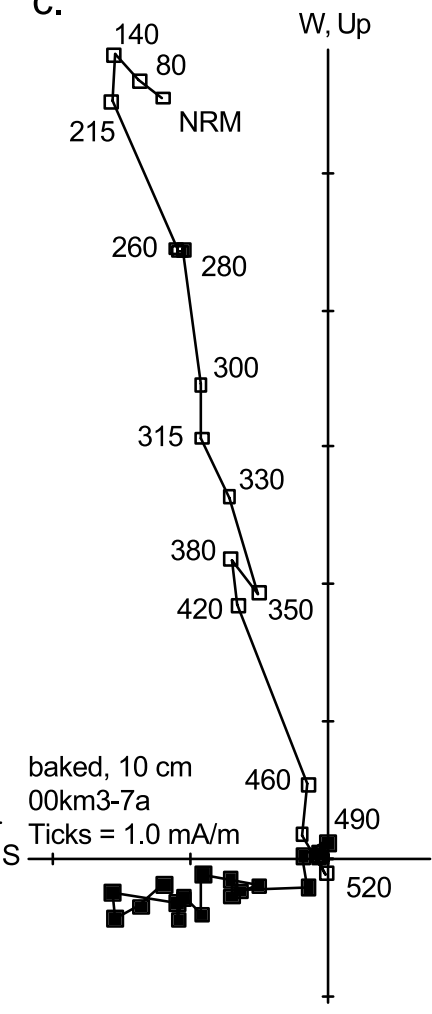

d.

$S$
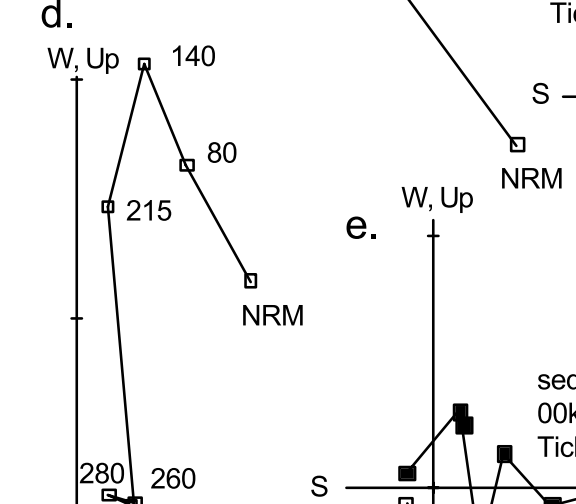

260

300

NRM

sed, $605 \mathrm{~cm}$

$00 \mathrm{~km} 3-13 \mathrm{a}$

Ticks $=0.5 \mathrm{~mA} / \mathrm{m}$

$s$

580

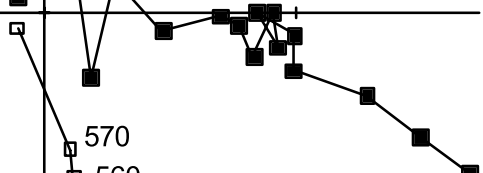

f.
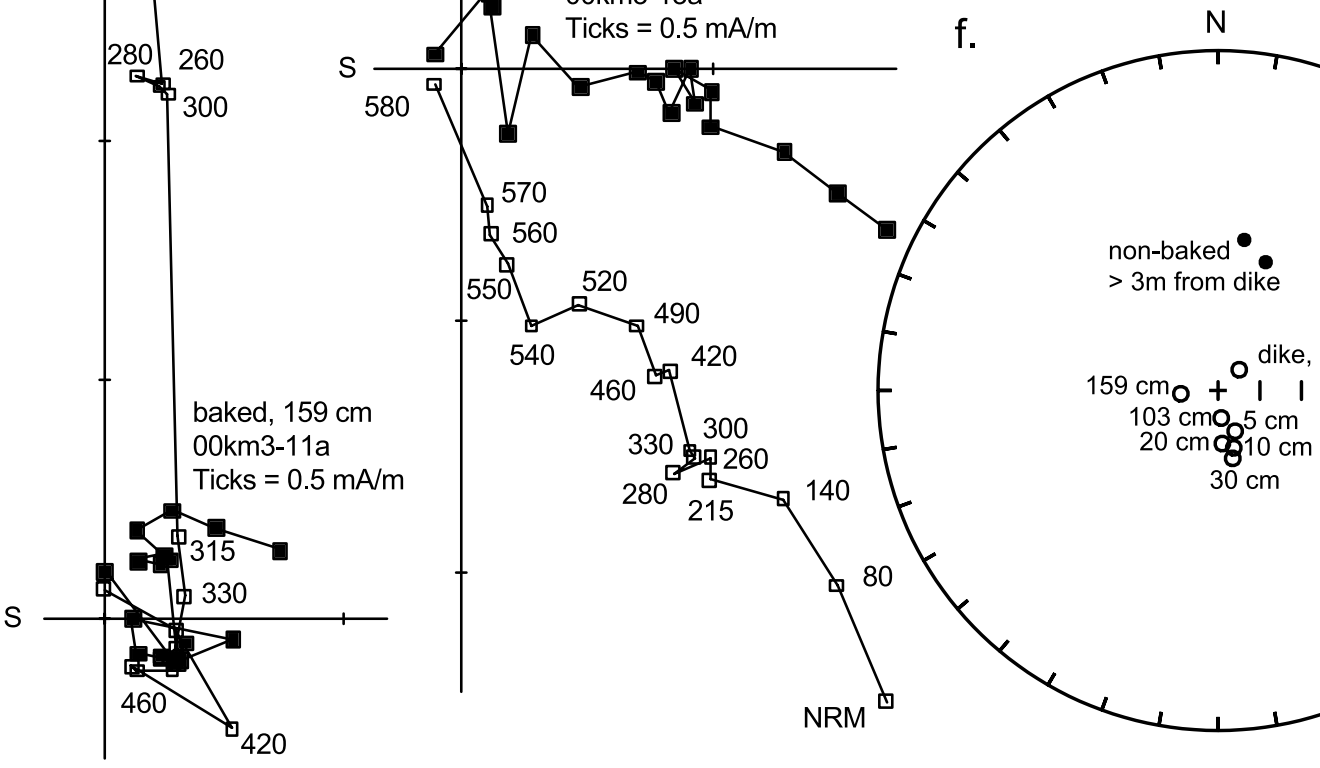

Q 560

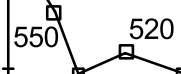

490

540

460

-
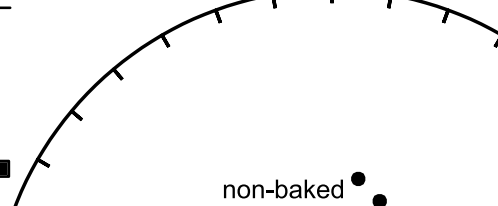

Figure 5. Orthogonal vector plots of demagnetization experiments from site $00 \mathrm{Km} 3$ for the bakedcontact test. (a) Result typical of the dike, with steeply up second-removed component. (b-d) Results of from samples of the baked-contact zone (distance from dike margin given for each sample). All samples have steeply upward second-removed components; the unblocking temperature of this component decays as a function of distance from the dike margin, as would be expected for a TRM. (e) Results from samples more than $3 \mathrm{~m}$ from dike margin, which lack the steeply upward second-removed component and instead have second-removed components that are similar to that of the surrounding area (compare with Figure 3). (f) Equal-area plot of direction of second-removed components from all dike, baked zone, and unbaked zone samples. 


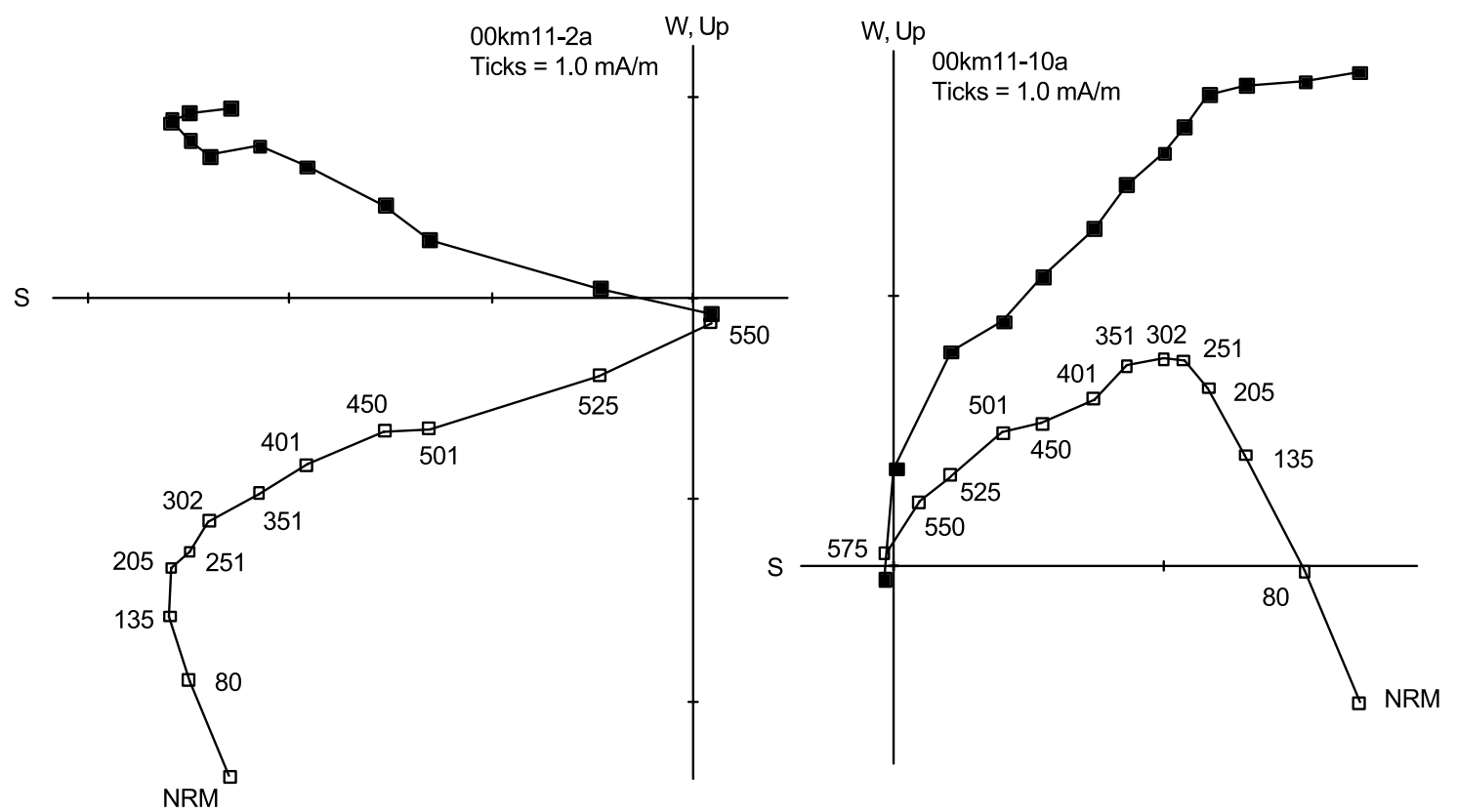

Figure 6. Orthogonal vector plots of representative demagnetization experiments of samples from conglomerate clasts of the Gable Creek Formation (site 00Km11).

mean inclination of the southern group of sites. This yielded a mean $\mathrm{I}=58.3^{\circ}, \mathrm{k}=130, \alpha_{95}=4.0^{\circ}$, $\mathrm{N}=11$, which compares favorably with the overall mean direction.

[21] The northern group of sites exhibit more complex behavior. Using the Tauxe and Watson [1994] fold test, the peak clustering occurs at about $40 \%$ untilting, with $95 \%$ confidence ranging from -22 to $50 \%$ untilting (Figure 12). Use of any of the other fold tests yields a similar result, and thus we conclude that the sites located north of the Mitchell Fault fail the paleomagnetic fold test. As can be seen in Figure 12b, the six tilt-corrected site mean directions cluster in pairs that correspond to the geographic area in which the site is located. The clusters of directions also form a well defined great circle; this can be consistent with dispersion due to an unaccounted for generation of folding that has affected the area north of the Mitchell Fault, rather than simple vertical axis rotations between localities. We attribute failure of the fold test for the sites in this area to additional structural complexity and perhaps to a more complicated history of magnetization as well. More detailed structural and paleomagnetic sampling would be needed to determine the nature of deformation and its relationship to the age of magnetization in the area north of the Mitchell Fault. The paleogeographic interpretations described below will use paleomagnetic data from sites south of the Mitchell Fault.

\subsection{Magnetic Hysteresis}

[22] Magnetic hysteresis, using a peak field of 0.8 to $1.0 \mathrm{~T}$ was measured for a total of 67 specimens. The hysteresis loops were of standard shape (Figure 13), and the samples as a whole had relatively low coercivity values $\left(H_{c} 4\right.$ to $20 \mathrm{mT}$ ). The hysteresis parameters were plotted on a Day et al. [1977] plot, with the data for single domain-multidomain (SD-MD) admixtures from Dunlop [2002] plotted for comparison. The data from the Gable Creek and Hudspeth
Fm specimens all plotted within the pseudo-single domain (PSD) field of the Day plot (Figure 14), suggesting that the specimens contain either an assemblage of true PSD grains, or admixtures of SD and MD sized magnetite. Given the clastic nature of the sediments, the latter interpretation is more likely. Results from site $00 \mathrm{Km} 15$, which we infer to

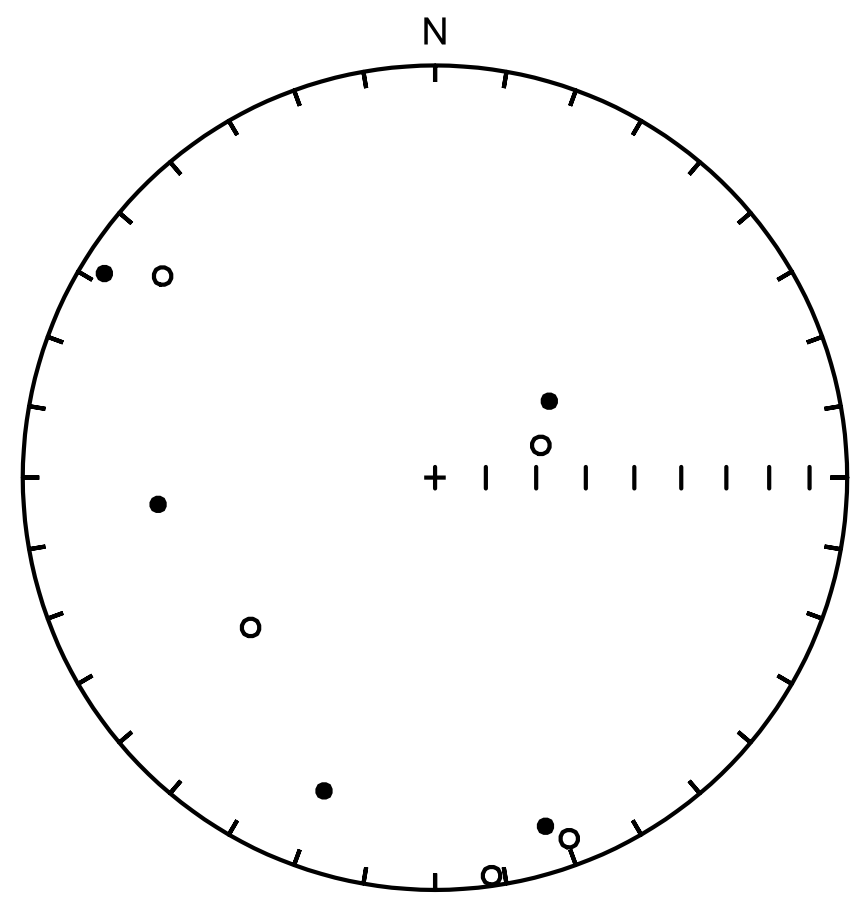

Figure 7. Equal-area plot of second-removed magnetization component directions from conglomerate clast samples (site $00 \mathrm{Km} 11$ ). The directions are widely scattered and statistically random, providing a positive intraformational conglomerate test for the Gable Creek Formation. 


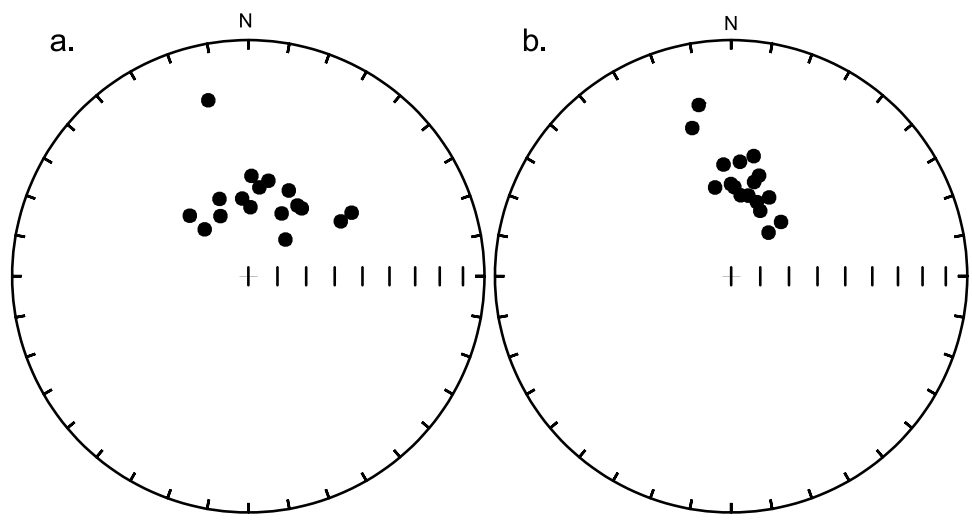

C.

95\% confidence: 46 - $78 \%$ untilting

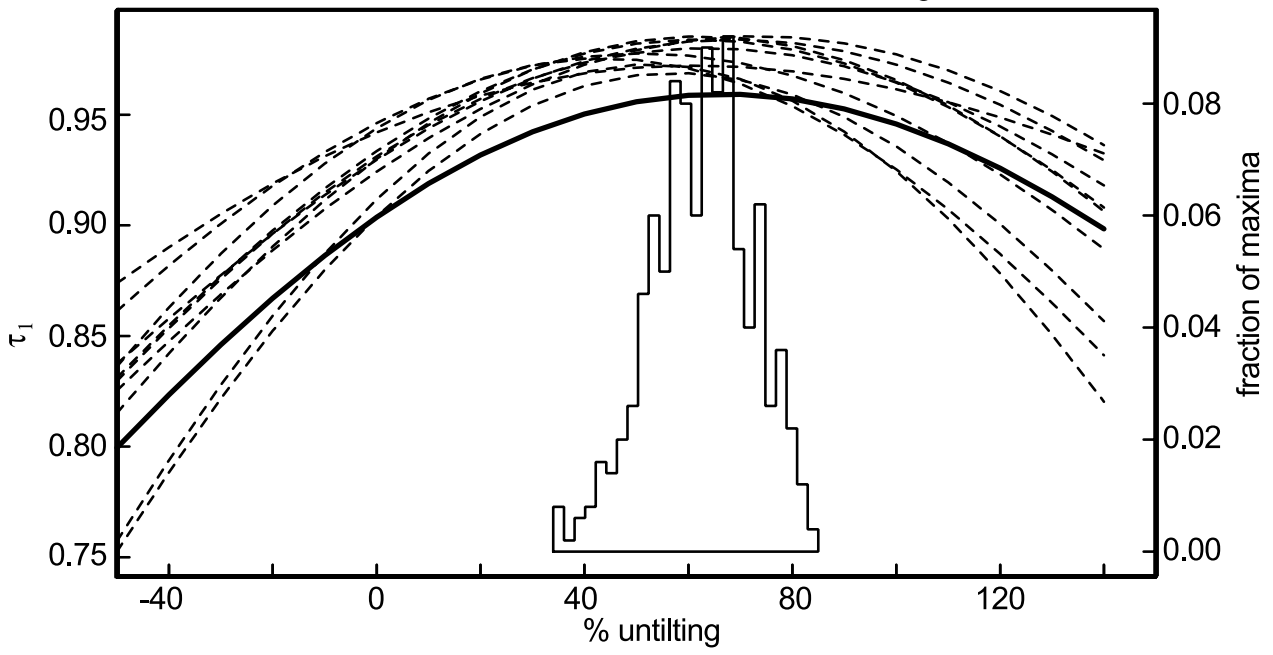

Figure 8. Tauxe and Watson [1994] nonparametric paleomagnetic fold test for all sites. Equal-area projection of site mean directions (a) in in situ and (b) in tilt-corrected coordinates. (c) Plot of incremental fold test results. The maximum principal eigenvalue $\left(\tau_{1}\right)$ of the orientation matrix calculated from the site mean directions will be maximized when the directions are most tightly grouped. The dashed lines represent the variation in $\tau_{1}$ as a function of percent untilting for 20 artificial paradata sets produced by the nonparametric bootstrap. The solid line represents the variation in $\tau_{1}$ of the actual data. The histogram is of the percent untilting at which $\tau_{1}$ is maximized for a set of 500 bootstrapped paradata sets; $95 \%$ of these data have maxima between 46 and $78 \%$ untilting; thus this fold test rules out a 100\% untilting result at $95 \%$ confidence.

have been remagnetized, have hysteresis parameters that lie toward the SD end of the distribution defined by the unremagnetized sites.

\subsection{Anisotropy of Magnetic Susceptibility (AMS)}

[23] Anisotropy of magnetic susceptibility (AMS) measurements were made on 161 specimens. Mean susceptibility varied between $1 \times 10^{-4}$ to $3 \times 10^{-3}$ SI units. The degree of anisotropy $\left(P=k_{\max } / k_{\min }\right)$ varied from 1.01 to 1.11 , with higher $P$ values corresponding to samples with higher mean susceptibilities. The shapes of most AMS ellipsoids fall within the oblate field of a Flinn-type plot (Figure 15). Analyzed on the site level, the AMS ellipsoids are statistically triaxial [Tauxe, 1998] for most sites. The orientations of the AMS axes, after correction for bedding tilt, have $k_{\min }$ axes that are subparallel to bedding poles (Figures 16a and 16b) in many sites. Other sites have AMS $k_{\min }$ orientations that are distinctly streaked, with AMS foliation planes oblique to bedding (Figures 16c and 16d). Such distributions of AMS orientations are consistent with fabrics observed in clastic sediments [see Tarling and Hrouda, 1993], and indicate that the AMS records the influence of paleocurrent and/or slope transport processes.

\subsection{Evaluation of Inclination Error}

[24] Before evaluating the possible tectonic significance of the paleomagnetic results from this study, we first evaluate the possibility that an inclination error affects the remanence. Anomalously shallow inclinations can result from both mechanical processes during primary deposition and the effects of postdepositional compaction [King, 1955; Tauxe, 1993]. Recognition of, and correction for, the amount of inclination error in sedimentary rocks is difficult. We will use three approaches to address this question.

[25] The first approach is to examine results from rocks with differing lithologies and sediment grain sizes, with the idea that clay-rich turbidite units should have larger degrees of possible inclination error (due to adhesion of magnetite particles to clay minerals [Sun and Kodama, 1992]). In contrast, sandstone beds, early cemented concretions, and 


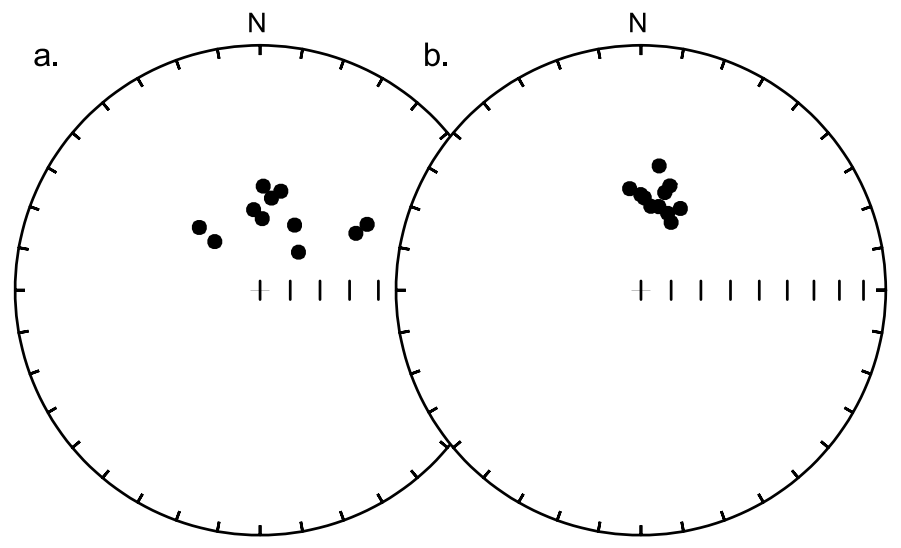

c. 95\% confidence: 66 - 103\% untilting

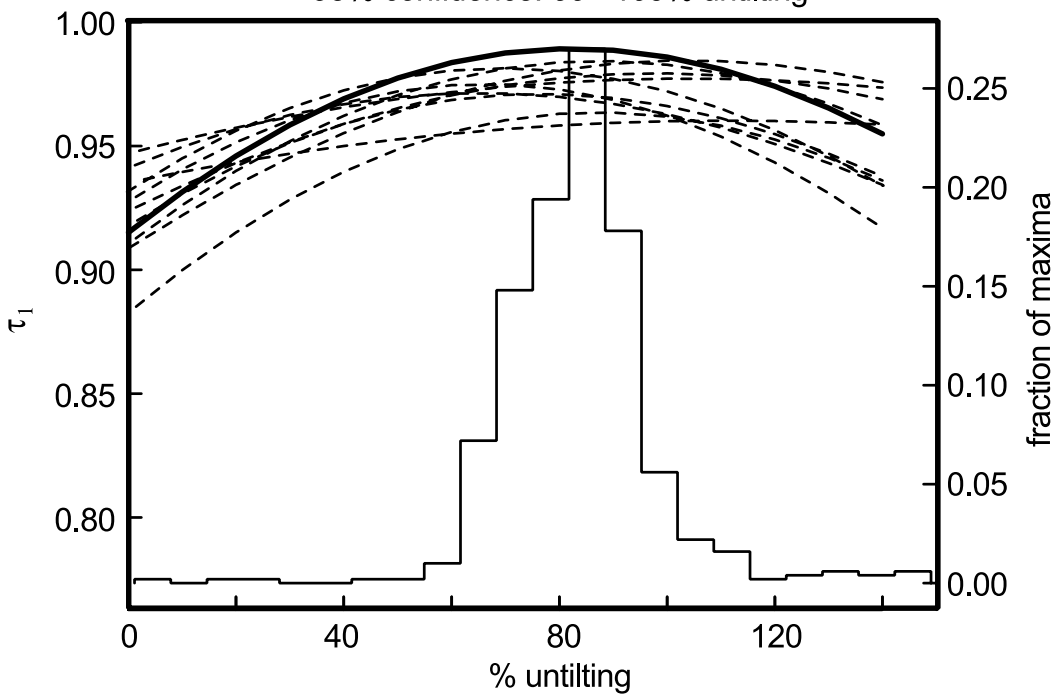

Figure 9. Results of Tauxe and Watson [1994] parametric bootstrap fold test for sites south of the Mitchell Fault. (a) Equal-area projection of site mean directions in in situ coordinates and (b) equal-area projection of site mean directions after $100 \%$ untilting. (c) Fold test results (as in Figure 8), showing peak in untilting includes $100 \%$ untilting at $95 \%$ confidence; thus these results pass the paleomagnetic fold test.

certain other lithologies may be less prone to inclination error (see discussion by Dickinson and Butler [1998] and Enkin et al. [2003]) than clay-rich turbidites. We observed no systematic variation in the inclinations obtained from the variety of lithologies we sampled.

[26] The second approach is to use magnetic anisotropy fabrics, such as AMS, to evaluate possible relationships between the degree of particle alignment in sedimentary rocks and measured inclination. The basic premise of this approach is that the true inclination of the geomagnetic field will only be recorded by sediments with a perfectly random mineral preferred orientation fabric [see Jackson et al., 1991], and that there will be a predictable relation between fabric intensity and the amount of inclination error. The relation, however, is strongly influenced by mineral shape, particularly when using remanence anisotropy measurements [Jackson et al., 1991; Kodama, 1997]. To account for grain shape, magnetic separates of ground-up sedimentary rocks are often made to determine the average aspect ratio of the magnetite grains, which then enable the relationship between magnetic mineral alignment and paleo- magnetic inclination to be quantitatively evaluated [see Kodama, 1997; Kim and Kodama, 2004]. An alternate approach was suggested by Hodych et al. [1999], who examined the relationship between observed and predicted paleomagnetic inclinations and magnetic fabrics (both AMS and anisotropy of ARM) in sediments. They concluded that a simple linear correlation between the tangent of measured inclination, and 1/P (degree of magnetic anisotropy) would yield a first-order correction for inclination error. Although less robust than the Jackson et al. [1991] and Kodama [1997] methods, it has an advantage in eliminating the uncertainty in use of magnetic separates (which are biased toward larger grain sizes), and it is far easier to perform. The results of this analysis (Figure 17) indicate a weak correlation between AMS fabric intensity and inclinations. Projecting the correlation line to a random fabric produces a predicted true inclination of $62^{\circ}$, which would suggest a maximum estimate of $4^{\circ}$ of inclination error. We note, however, that this correlation is almost entirely based on the few specimens with degrees of anisotropy $>1.04$, and that the data set as a whole shows no clear relationship 


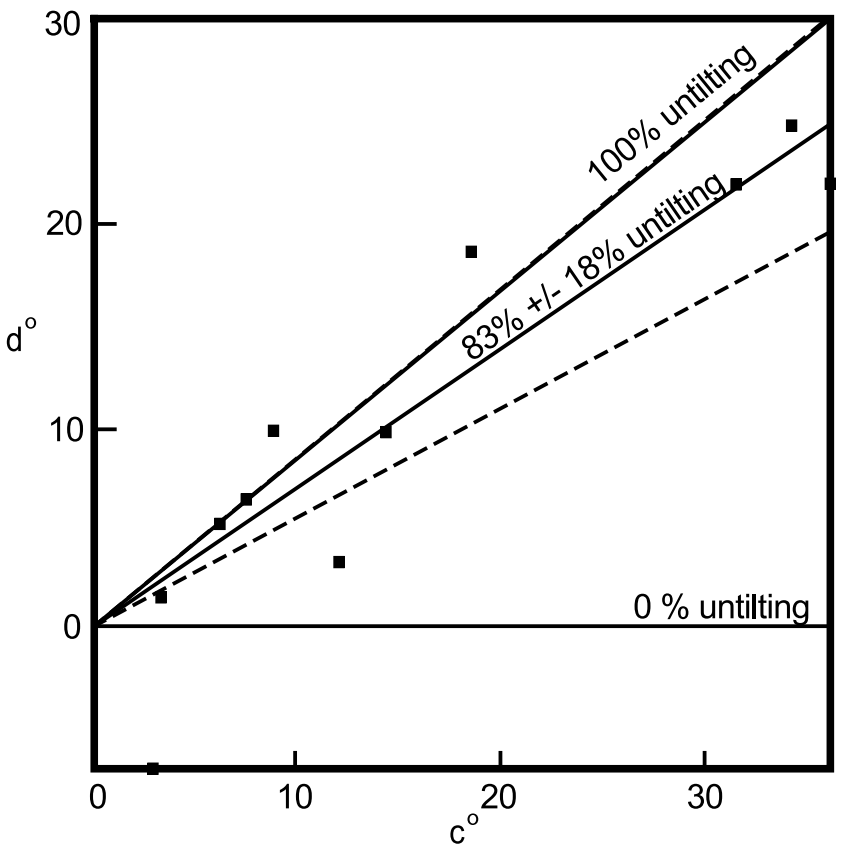

Figure 10. Results of DC tilt test of Enkin [2003] for sites south of the Mitchell Fault. The $c$ value represents the angle between the in situ group mean direction and the tiltcorrected site mean direction back rotated by the angular relationship between the in situ and tilt-corrected group mean directions. The $d$ value is a projection of the arc between in situ site mean directions and the in situ group mean direction onto the arc used to calculate the $c$ value. (See Enkin [2003] for details). The $c$ and $d$ values should be closely correlated if directions cluster significantly better upon $100 \%$ untilting $(d-c$ slope $=1.0)$. Results of this tilt test indicate maximum clustering of directions occurs at $83 \pm$ $18 \%$ untilting; thus these results also constitute a positive paleomagnetic fold test.

between fabric development and inclination (Figure 17). Large $\left(10^{\circ}\right.$ or greater) inclination error in these rocks appears to be ruled out by these data. The best interpretation of these data, given the weak correlation between fabric development and inclination, would be that no significant inclination error exists in these rocks.

[27] The third approach is to examine the spatial distributions of paleomagnetic directions to test for anomalous elongations that will be produced by inclination error [Tauxe and Kent, 2004; Krijgsman and Tauxe, 2004]. On the basis of geomagnetic field geometry (see Beck [1999] and Tauxe and Kent [2004] for discussion) a predictable relation exists between the shape (orientation and magnitude of N-S and E-W elongation) of directional data distributions and geographic latitude. An inclination error will introduce an anomalous E-W elongation of directional data. Because the shapes of directional data distributions can be sensitive to small errors, large data sets (100 or more sites for a studylevel calculation, and approximately 20 or more samples for a site-level evaluation) are called for by Tauxe and Kent [2004]. Application of this technique to the problem of displaced terranes can be complicated by structural factors. In regions subject to noticeable deformation, a significant complication will be the effect of vertical axis rotation between sites, which will also produce data that are elongate in E-W directions (see Beck [1999] for many good examples of this). The correction-by-site (CBS) method outlined by Tauxe and Kent [2004] may be superior for studies such as this, because the problem of unaccounted for vertical axis rotation will be avoided at the site level. The drawback of full implementation of the CBS method is that a large number of directions are needed for each paleomagnetic site. Tauxe and Kent [2004] suggested $>20$ samples per site would be required, while Beck [1999] demonstrated that 15 or more samples would be sufficient to ensure that the elongation of a single data set was significant at $95 \%$ confidence.

[28] Although we cannot fully implement the CBS method for our entire study, we do have one site $(00 \mathrm{Km} 9)$ with a large number of samples $(n=14)$, which nearly fulfills the Beck [1999] criteria. The elongation of the directional data, calculated according to either Tauxe [1998] or Beck [1999], has an $E=1.60$. Taking these same data, we corrected the inclinations by:

$$
\tan I_{c}=(1 / f) \tan \left(I_{m}\right)
$$

where $I_{c}$ is the corrected paleomagnetic inclination, $I_{m}$ is the measured paleomagnetic inclination, and $f$ is the paleomagnetic flattening factor. The inclination correction that produces the minimum elongation of the distribution of site-level directions provides the best estimate of the correct amount of inclination error [Tauxe and Kent, 2004]. Using trial calculations for $3^{\circ}, 5^{\circ}, 10^{\circ}$, and $15^{\circ}$ degree inclination errors $(f=0.89,0.82,0.65,0.49$, respectively), the calculated values for elongations of the directional data

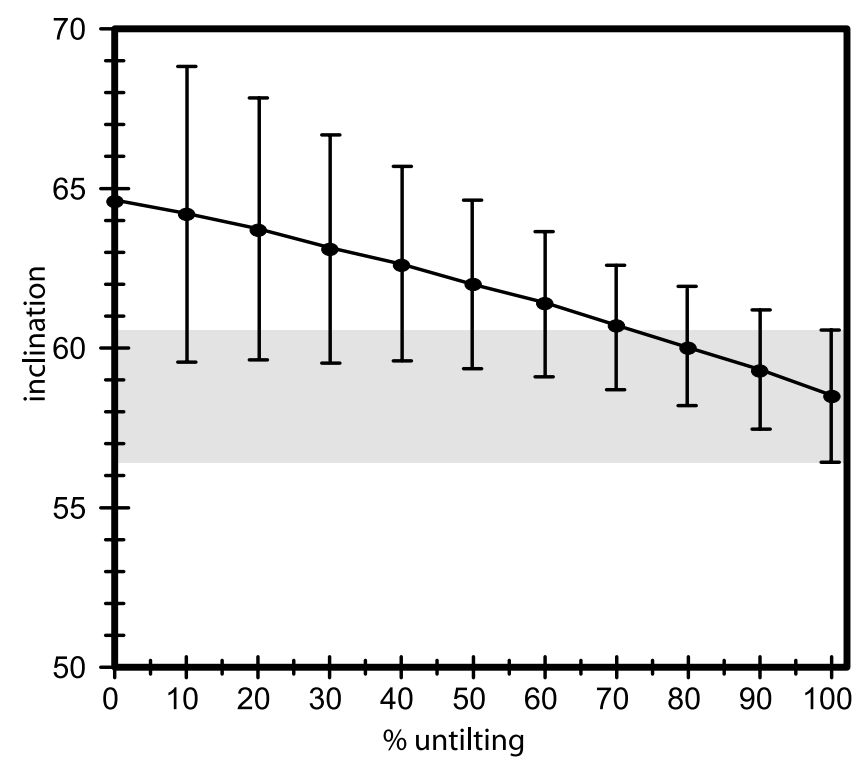

Figure 11. Mean inclination versus percent untilting for the 11 paleomagnetic sites located south of the Mitchell Fault. Error bars are at 95\% confidence, with the 95\% confidence limits for the $100 \%$ unfolding result shaded. There is only a small and statistically insignificant difference between the mean inclination at $100 \%$ untilting $\left(I=58.5^{\circ}\right)$ at the mean inclination at peak in directional clustering at $80 \%$ untilting $\left(I=60.0^{\circ}\right)$. 

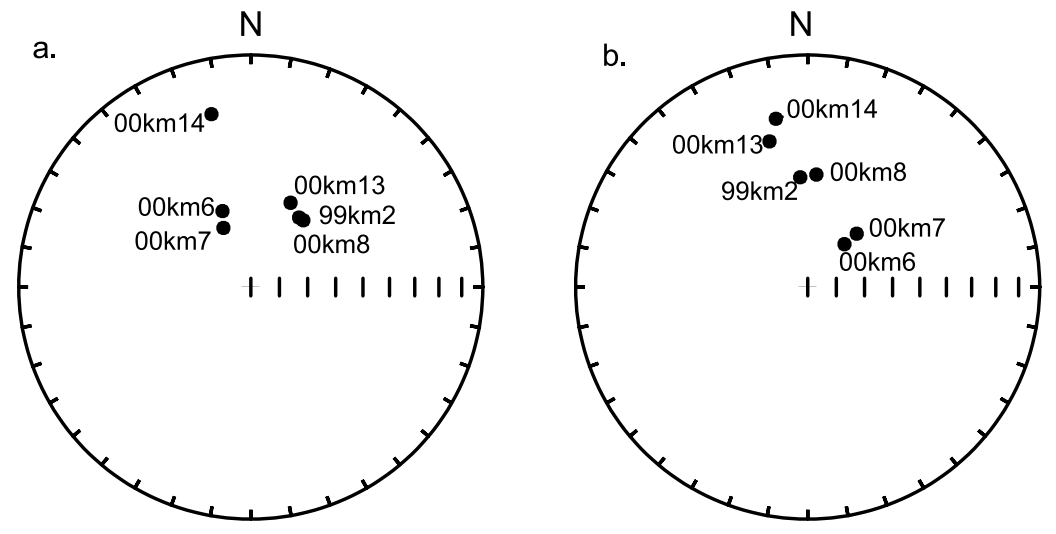

C.

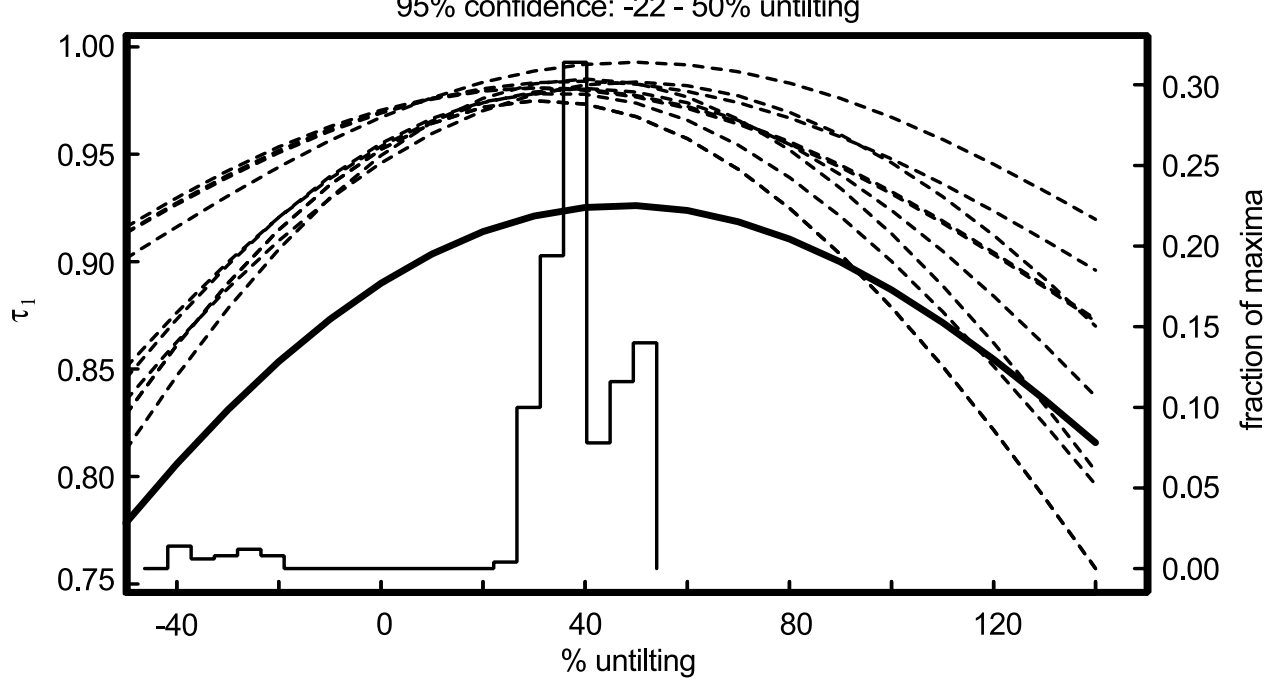

Figure 12. Results of Tauxe and Watson [1994] fold test for sites north of the Mitchell Fault. (a) Equalarea projection of site mean directions in in situ coordinates and (b) equal-area projection of site mean directions after 100\% untilting. (c) Fold test results (as in Figure 8), showing peak in untilting does not include $100 \%$ untilting at $95 \%$ confidence. Thus these results fail the paleomagnetic fold test.

distributions are $E=1.63,1.65,1.74,1.81$. Thus the minimum elongation occurs without any inclination correction ( $\mathrm{f}=1.0, \mathrm{E}=1.60)$, and indicates that no significant inclination error is present in the site $00 \mathrm{Km} 9$ rocks. To the extent that this single site is representative of the entire study, no correction for anomalously shallow inclinations is warranted.

[29] On the basis of all of the above we conclude that no significant inclination error is present in these rocks, so that the best estimate of the geomagnetic field's inclination as
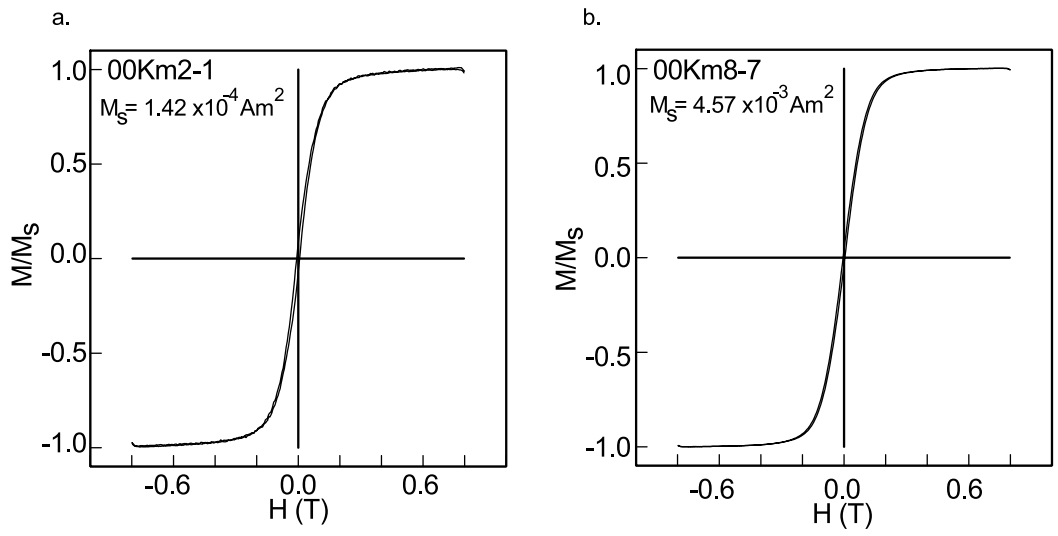

Figure 13. Representative magnetic hysteresis loops from (a) Gable Creek Formation and (b) Hudspeth Formation samples. Loops are corrected for high-field slope. 


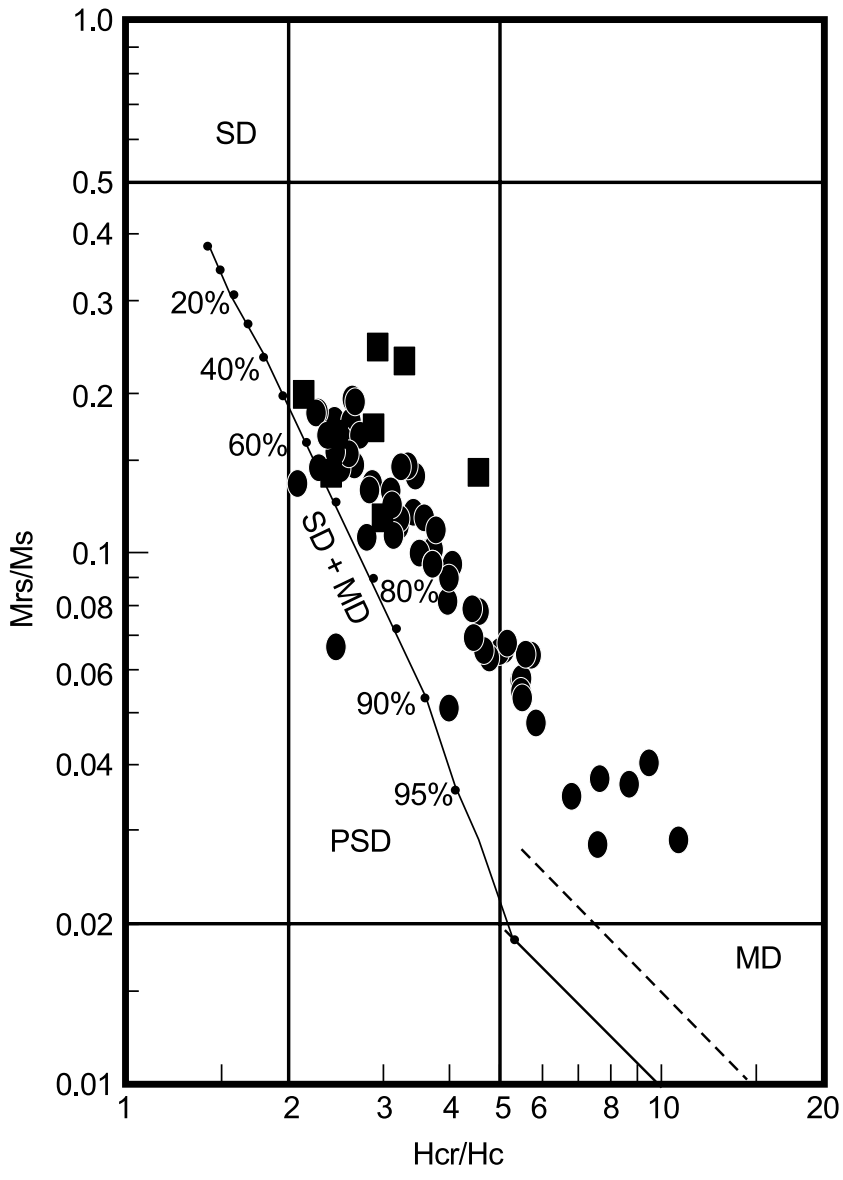

Figure 14. Modified Day et al. [1977] plot, with SD-MD mixing lines, from Dunlop [2002], showing hysteresis parameters of samples from the Gable Creek and Hudspeth formations. The results indicate the samples contain admixtures of SD and MD magnetite. The squares denote results from site $00 \mathrm{Km} 15$, which appears to have been remagnetized.

recorded by the Gable Creek and Hudspeth Formations is $58.5^{\circ}$. Unfortunately, the CBS method of Tauxe and Kent [2004], which we argue may be the best way to evaluate inclination error, is not applicable to our entire sample set and so we cannot rigorously rule out a minor amount of unrecognized inclination error. We thus include an alternate result with $5^{\circ}$ degrees of inclination error in the discussion of our data.

\subsection{Paleolatitude, Translation, and Rotation}

[30] Using the mean direction from the 11 sites south of the Mitchell Fault, a paleolatitude of $39.2^{\circ}+4.8^{\circ} /-4.3^{\circ} \mathrm{N}$ is obtained for the Gable Creek and Hudspeth Formations. Compared with the current location of these rocks on North America and using the recalculated mid Cretaceous NA reference pole from Housen et al. [2003], the expected paleolatitude of the study location is $55.1^{\circ} \pm 2.7^{\circ} \mathrm{N}$. The resulting paleolatitude anomaly is $15.9^{\circ} \pm 4.1^{\circ}$, indicating a northward translation of $1760 \pm 460 \mathrm{~km}$ and a $\mathrm{CW}$ rotation of $37^{\circ} \pm 7.3^{\circ}$ for these rocks with respect to North America since the mid-Cretaceous (93 Ma) (error limits after Demarest [1983]). If a $5^{\circ}$ inclination error is assumed, it would indicate a paleolatitude of $45^{\circ} \mathrm{N}$, and $1200 \pm 460 \mathrm{~km}$ of northward translation with respect to North America.

\section{Discussion}

[31] Our paleomagnetic study has shown that Cretaceous sedimentary rocks of the Mitchell Inlier recorded the geomagnetic field shortly after deposition, and that the magnetic inclination obtained from these rocks is most likely not affected by significant inclination error. Prior compilations of regional geology suggest that the various terranes of the Blue Mountains were amalgamated to each other by late Jurassic to early Cretaceous time [e.g., Brooks and Vallier, 1978; Dickinson, 1979; Avé Lallemant, 1995]. This suggestion is consistent with the observation that Cretaceous sedimentary rocks of the Mitchell Inlier, and smaller exposures of similar rocks such as the Bernard Formation in the Suplee-Izee area, overlap the Baker and Izee terranes in the western Blue Mountains [e.g., Dickinson and Thayer, 1978; Kleinhans et al., 1984]. Thus it is possible that our paleomagnetic results can be used to constrain the Cretaceous paleogeography of the Blue Mountains as a more or less intact tectonic block. Alternatively, the Mitchell Inlier may represent a relatively small forearc sliver that experienced more translation than central and eastern parts of the Blue Mountains where mid-Cretaceous strata are not preserved. Because of this uncertainty, we consider several hypotheses for reconstruction of Cordilleran terranes in and adjacent to the Blue Mountains (section 6.4, below).

\subsection{Rotation of the Blue Mountains}

[32] Our paleomagnetic result provides a new constraint on the timing and amount of CW crustal rotation in the Blue Mountains. As mentioned above, most tectonic models that suggest significant rotation of the Blue Mountains rely on the study of Blue Mountains plutons by Wilson and Cox

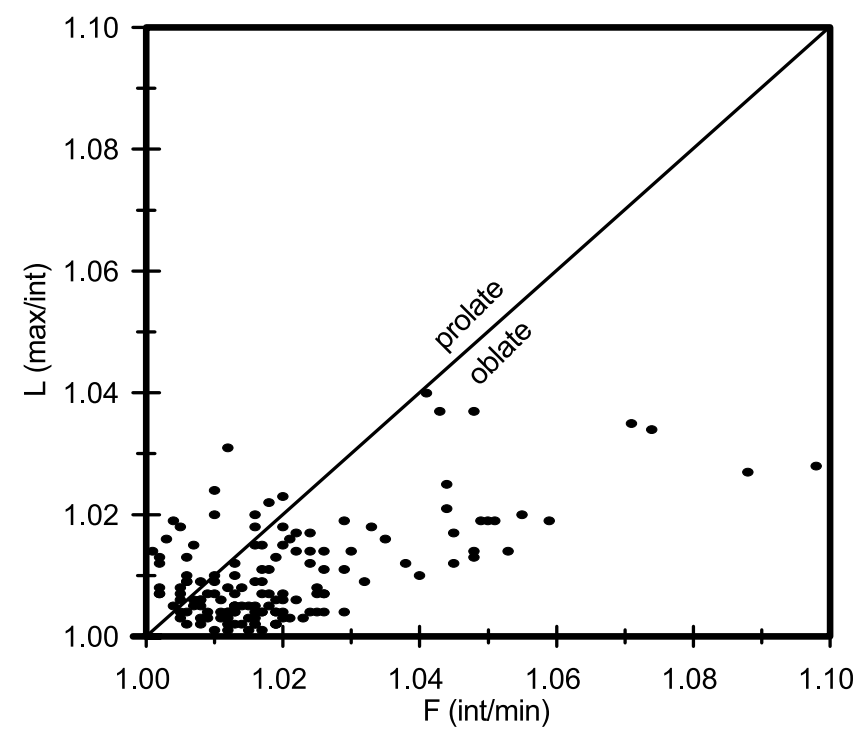

Figure 15. Flinn-type plot of AMS principal susceptibilities. The results indicate most samples have low to moderate degrees of anisotropy and that most have oblate to weakly triaxial ellipsoid shapes. 


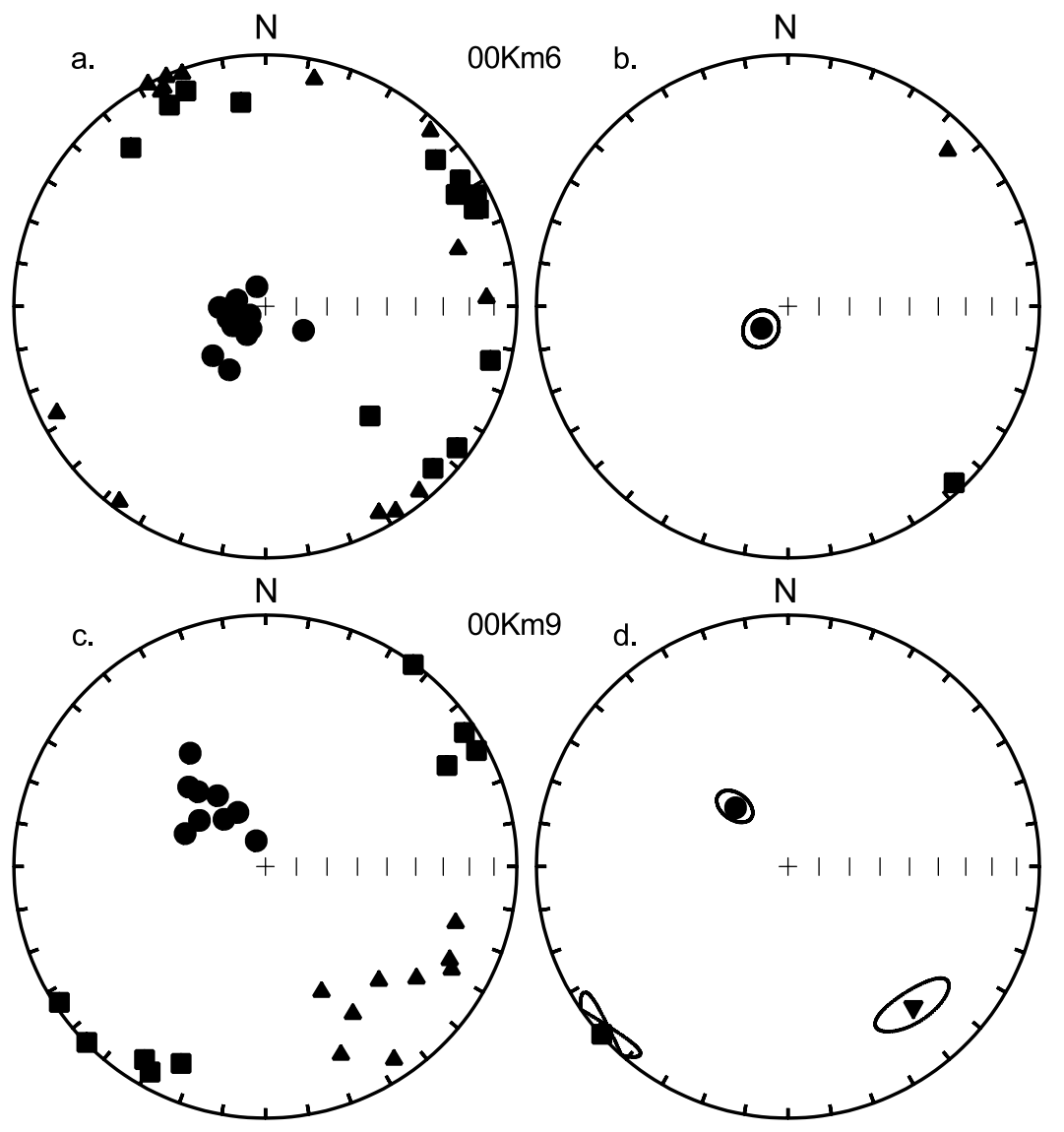

Figure 16. Examples of AMS orientations for typical sites, displayed in tilt-corrected coordinates. Orientations of $k_{\max }$ are denoted by squares, $k_{\text {int }}$ are denoted by triangles, and $k_{\min }$ are denoted by circles. Means for the axes were calculated using programs of Tauxe [1998] and are shown in Figures 16b and 16c. (a and b) Results for site $00 \mathrm{Km} 6$, which have $k_{\min }$ axes that are perpendicular to bedding and unixial-oblate ellipsoid shapes. (c and d) Results for site $00 \mathrm{Km} 9$, which has streaked $k_{\min }$ orientations and triaxial ellipsoid shapes, which are likely recording sediment transport processes during deposition.

[1980], who inferred $60^{\circ}$ of CW rotation since Early Cretaceous time. Because their study was based on a very small number of sites and samples, and has no firm paleohorizontal control for those rocks, significant uncertainty should be attached to their rotation estimate. Because our results come from stratified rocks with tight controls on the age of magnetization, our estimate of $37^{\circ} \pm 7.3^{\circ}$ of $\mathrm{CW}$ rotation relative to North America provides a better constraint of the history of vertical axis rotations of the Blue Mountains. For example, Dickinson [2002] calls for $50^{\circ}$ $\mathrm{CW}$ rotation of the Blue Mountains as part of a regional transrotation phase during Neogene time. Our rotation estimate instead suggests that $\sim 21^{\circ} \mathrm{CW}$ rotation of the Blue Mountains occurred after mid Cretaceous time and before deposition of the Early-Middle Eocene Clarno volcanics, with the remaining $16^{\circ}$ occurring after Eocene time [Grommé et al., 1986]. The timing and sense of this rotation agree well with that proposed by Dickinson [2002], although the net amount is substantially less.

[33] The Late Cretaceous timing and CW sense of rotation obtained from this study is also consistent with the larger pattern of $\mathrm{CW}$ rotation observed in rocks from terranes throughout the North America Cordillera [see Beck, 1980]. This sort of rotation is consistent with long-lived dextral shear along this convergent margin produced by a combination of block-scale rotation [Beck, 1976] and possible penetrative shear strain distributed throughout the convergent plate boundary zone [e.g., England and Wells, 1991].

\subsection{Cretaceous Paleogeography of the Blue Mountains}

[34] The paleolatitude of the Blue Mountains indicated by our paleomagnetic study places this large set of terranes approximately $1700 \mathrm{~km}\left(\sim 1200 \mathrm{~km}\right.$ if we assume a $5^{\circ}$ inclination error) south of their present location in midCretaceous time. Multiple paleomagnetic tests show that the age of magnetization is syndepositional. Thus we infer that northward translation of the Mitchell Inlier could have begun as early as the end of Cenomanian time (circa $93 \mathrm{Ma}$ ). The Mitchell Inlier and associated rocks of the Blue Mountains are constrained to be in their present location with respect to North America by the paleomagnetic result from the overlying Clarno Formation [Grommé et al., 1986]. Newer geochronology of the Clarno volcanics indicates these rocks are 54-43 Ma in age [Bestland et al., 1999]. Taken together, the time available for translation of the Mitchell Inlier, and possibly the entire Blue Mountains province, is about 48 m.y. These dates imply a minimum 


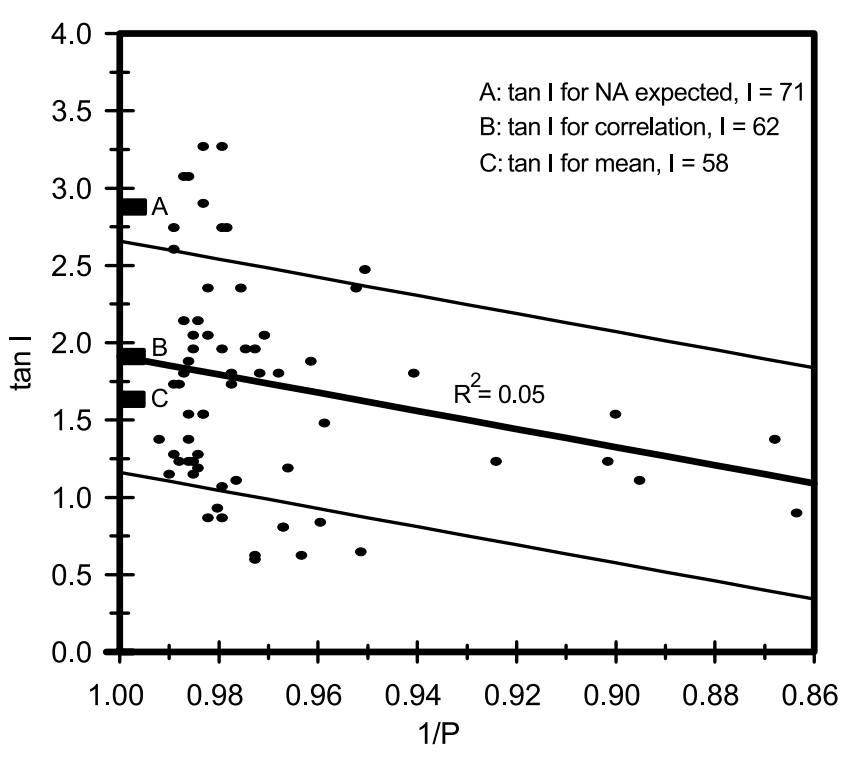

Figure 17. Correlation plot of magnetic fabrics and paleomagnetic inclinations [after Hodych et al., 1999]. Inclinations are in $100 \%$ tilt-corrected coordinates and are compared to AMS degree of anisotropy $\left(P=k_{\max } / k_{\min }\right)$. Hodych et al. [1999] demonstrated that inclination error produces a linear relationship between $\tan (I)$ and $1 / P$, with the intercept of the correlation line $1 / P=1.00$, signifying a totally random fabric, providing the best estimate of the original paleomagnetic inclination using this technique. These results show only a weak correlation $\left(R^{2}\right.$ and $95 \%$ confidence intervals for correlation line are shown) between $\tan (I)$ and $1 / P$, indicating that little or no significant inclination error has occurred in these rocks. Values of tan (I) and resulting inclination estimates for no displacement (A), the proposed correlation correction from this plot (B), and for the mean inclination from these data (C) are shown.

time-averaged relative plate motion of $\sim 35 \mathrm{~mm} / \mathrm{yr}$ for the larger displacement $(1700 \mathrm{~km})$, and $\sim 25 \mathrm{~mm} / \mathrm{yr}$ for the lower estimate $(1200 \mathrm{~km})$.

[35] If terranes of the Blue Mountains have remained relatively intact since Late Jurassic or Early Cretaceous time, the results of our study will require substantial revision of paleogeographic models that place the Blue Mountains in their present position relative to North America prior to Late Cretaceous time [e.g., Dickinson and Thayer, 1978; Lund and Snee, 1988; Selverstone et al., 1992; Avé Lallemant, 1995; Cowan et al., 1997; Wyld and Wright, 2001; Dickinson, 2004]. Several of these models [e.g., Wyld and Wright, 2001] argue that the Blue Mountains are pinned to the margin of North America through the Salmon River Suture Zone and Western Idaho Shear Zone (WISZ) by crosscutting relationships involving plutons of the $118 \mathrm{Ma}$ Hazard Creek and $110 \mathrm{Ma}$ Little Goose Creek complexes and the $90 \mathrm{Ma}$ Payette River tonalite [Lund and Snee, 1988; Manduca et al., 1993; Selverstone et al., 1992]. The presence of xenoliths and roof pendants belonging to both the North American craton and oceanic Blue Mountains terranes, in a zone that straddles the isotopically defined cratonal margin, requires that these plutons intruded across the continent-ocean suture during or after initial accretion of oceanic terranes to North America [Armstrong et al., 1977; Fleck and Criss, 1985; Criss and Fleck, 1987; Manduca et al., 1992]. However, these intrusions do not place any constraint on post mid-Cretaceous translation of the Blue Mountains. Indeed, plutonic rocks in the WISZ and eastern Idaho batholith have experienced multiple phases of penetrative transpressional deformation during and after their emplacement [Manduca et al., 1993; McClelland et al., 2000]. The Hazard Creek and Little Goose Creek complexes are highly deformed, and the relatively undeformed Payette River tonalite is located well east of the relevant tectonic zone [see Manduca et al., 1993]. McClelland et al. [2000] showed that penetrative structures in the WISZ record a significant, though unknown amount of dextral shear between the Blue Mountains and cratonal North America during latest Cretaceous time. Our paleomagnetic data are consistent with their structural model and suggest that the WISZ was the locus of large-scale dextral displacement between about 93 and $45 \mathrm{Ma}$.

[36] Wyld and Wright [2001] proposed that the Blue Mountains province was located $\sim 400 \mathrm{~km}$ to the south of its present location in the early Cretaceous based on correlations between similar Jurassic rocks in the Blue Mountains and in the Black Rock Desert of western Nevada. Part of their paleogeographic model includes connections between dextral strike-slip fault systems in southern and central California (Mojave-Snow Lake and Sierra Crest shear zones), the Western Nevada shear zone, and the WISZ-Salmon River Suture Zone to form a major transform fault system. The Blue Mountains lie immediately to the west of this large structure (Figure 1), which makes this fault system a very attractive candidate to accommodate at least a portion of the large (1200 to $1700 \mathrm{~km})$ displacement of the Blue Mountains that we propose here.

\subsection{Regional Correlation of Cordilleran Terranes}

[37] Any attempt to reconstruct the paleogeography of the Blue Mountains requires consideration of possible correlations to other Cordilleran tectonic elements. Some workers have argued, mainly based on similarities between Permian and Triassic rocks of Wrangellia and the Seven Devils rocks of the Wallowa terrane, that the Blue Mountains province correlates to the Insular superterrane [Jones et al., 1977; Hillhouse et al., 1982; Wernicke and Klepacki, 1988; Dickinson, 2004]. Others suggest that the geochemistry and petrology of the same Triassic units argues against associations between the Seven Devils rocks and Wrangellia, and instead suggest a correlation between the Blue Mountains and the Intermontane superterrane [Sarewitz, 1983; Mortimer, 1986]. As discussed by Mortimer [1986], either of these two correlations is permitted by existing paleomagnetic data from Triassic rocks of the Insular and Intermontane superterranes and the Blue Mountains. Although we cannot test these correlations between Triassic units with our data, we can compare high-quality paleomagnetic data from mid Cretaceous units from the Insular and Intermontane superterranes to new data from the Mitchell Inlier (this study). For this comparison we use the circa 90 Ma paleomagnetic results from Mount Tatlow [Wynne et al., 1995], the upper Churn Creek rocks [Enkin et al., 2003], and the Mount Stuart batholith [Housen et al., 2003] for the Insular superterrane, and the 100-105 Ma 


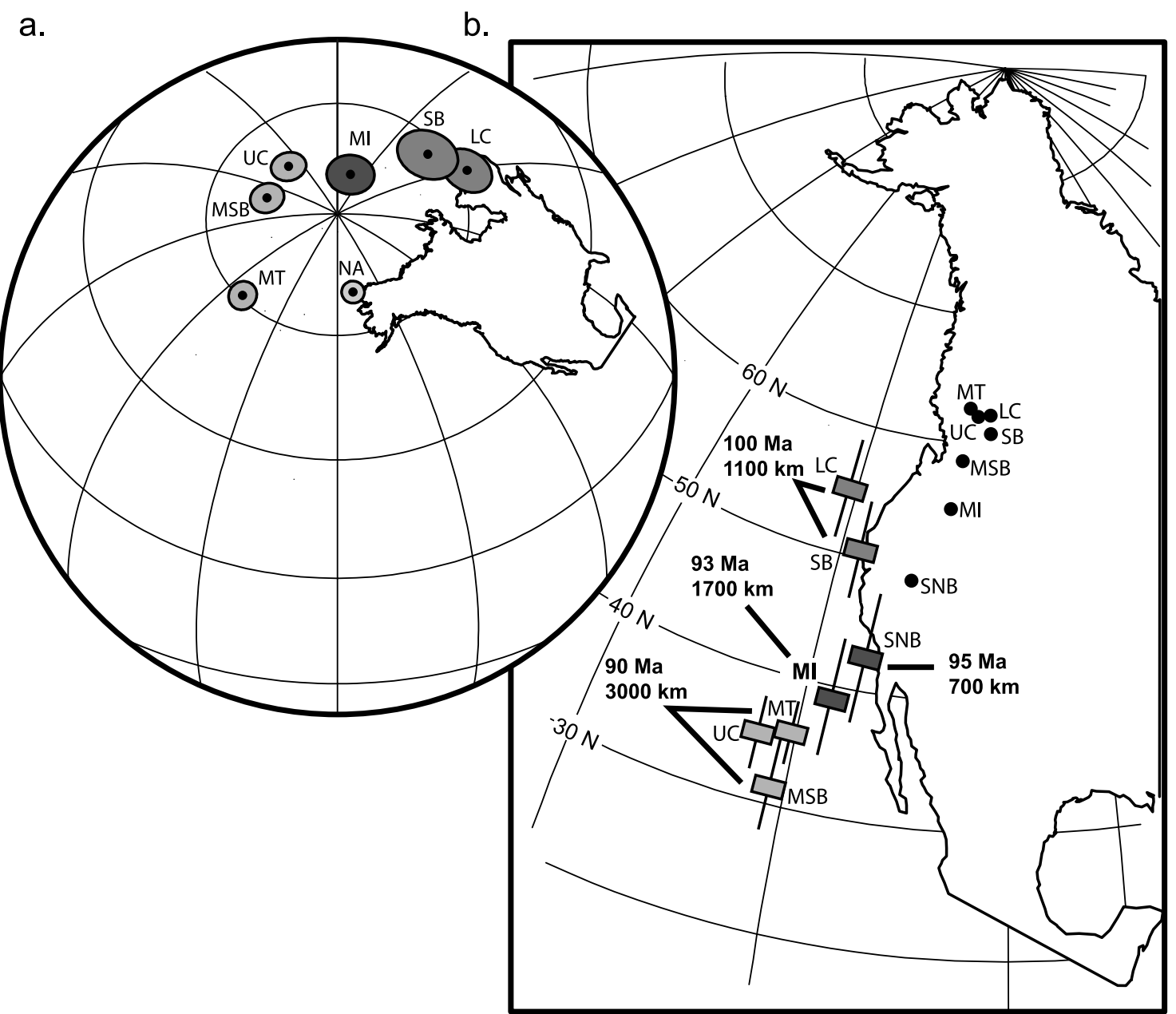

Figure 18. (a) Paleomagnetic poles calculated for tilt-corrected results from this study (MI pole). Also plotted are the mid-Cretaceous NA reference pole [Housen et al., 2003], poles for units in the Insular superterrane with high-quality results (MT, Mount Tatlow [Wynne et al., 1995]; UC, upper Churn Creek [Enkin et al., 2003]; MSB, Mount Stuart batholith [Housen et al., 2003]) and poles from units in the Intermontane superterrane with high-quality results (SB, Spences Bridge [Irving et al., 1995]; LC, lower Churn Creek [Haskin et al., 2003]). (b) Paleogeographic map showing position of North America, reconstructed using the Housen et al. [2003] NA pole. Paleolatitudes, with $95 \%$ confidence bars, for the paleomagnetic results in Figure 18a and the paleolatitude of the Sierra Nevada (SNB) [Frei et al., 1984; Frei, 1986] are shown. The ages of magnetization for each set of results and the post-Cretaceous amounts of northward translation are also given. The labeled dots denote the study locality for each paleomagnetic result.

Spences Bridge volcanics [Irving et al., 1995] and lower Churn Creek rocks [Haskin et al., 2003] of the Intermontane superterrane. Plotting the paleomagnetic poles for each of these units, along with those calculated from the Gable Creek and Hudspeth Formations (Figure 18a), we see that the coeval poles from the Insular superterrane are significantly more far-sided than those of the Blue Mountains. This difference reflects the shallower inclinations, and lower resulting paleolatitudes, of the Insular superterrane units (Figure 18b). In contrast, the poles of the Intermontane units, though slightly older, are more similar to the Blue Mountain pole (Figure 18a). Comparing the Cretaceous paleolatitudes of these units (Figure 18b), we find that the amount of latitudinal translation and relative position of the Blue Mountains compares more favorably with that of the Intermontane superterrane. On this basis, we tentatively conclude that our paleomagnetic study supports correlations between the Blue Mountains province and the Intermontane superterrane, as proposed by Mortimer [1986], and suggests they shared a similar post mid-Cretaceous displacement history.

[38] It is also important to consider the correlation between terranes of the Blue Mountains and Klamath Mountains, SW Oregon, which has been suggested on the basis of similarities between the mid- to Late Cretaceous Hornbrook Basin in the Klamath Mts. and the Mitchell Inlier (Ochoco basin) of the Blue Mountains [Kleinhans et al., 1984; Nilsen, 1986]. Other paleogeographic models also link the Klamaths and Blue Mountains during the Cretaceous [see Dickinson, 1979, 2002, 2004; Wilson and Cox, 1980; 
Grommé et al., 1986; Wyld and Wright, 2001]. If this correlation is correct, rocks in the Klamath Mountains should have a mid Cretaceous paleolatitude similar to that indicated by our paleomagnetic study. There is a limited (2 sites) paleomagnetic data set from the Hornbrook Formation [Mankinen and Irwin, 1982]. These results were originally compared with coeval rocks of the Great Valley Group, and found by Mankinen and Irwin [1982] to fail a regional fold test on that basis. The tilt-corrected directions for the Hornbrook Formation reported by Mankinen and Irwin, [1982] are essentially identical to those we have found from the Mitchell Inlier rocks supporting a link between the Hornbrook and Ochoco Basins during the mid-Cretaceous. Unfortunately the small number of sites in the Hornbrook Formation makes a detailed statistical comparison between the two studies of limited significance.

[39] The Klamaths and Sierra Nevada arc are commonly treated as a single entity for most of Mesozoic time in many compilations of regional geology [e.g., Ingersoll and Schweickert, 1986; Saleeby, 1990; Hacker and Peacock, 1990; Hacker et al., 1995; Irwin and Mankinen, 1998; Irwin, 2003; Dickinson, 2004]. We can consider possible constraints on the paleogeographic position of the combined Klamaths-Sierra Nevada block that are suggested by our results in the Mitchell Inlier. The consensus of most paleogeographic models summarized above, as well as those of Dickinson and Butler [1998], Wyld and Wright [2001], Umhoefer [2003], Umhoefer and Blakey [2005], and Wyld et al. [2005], is that the Sierra Nevada arc was located at its present latitude $\left(49.1^{\circ} \mathrm{N}\right)$ relative to North America during the Cretaceous. Paleomagnetic data from midCretaceous Sierra Nevada plutons [Frei et al., 1984; Frei, 1986] indicate a paleolatitude of $42.8^{\circ} \pm 5^{\circ} \mathrm{N}$ for this arc. This result is commonly interpreted to indicate that little significant latitudinal translation of the Sierra Nevada has occurred since Late Cretaceous time, based on the overlap between the expected (in place with respect to North America) paleolatitude and the 95\% confidence interval on the paleolatitude calculated from the combined results of Frei et al. [1984] and Frei [1986]. The mid-Late Cretaceous reference pole for North America recalculated by Housen et al. [2003] has a somewhat smaller 95\% confidence interval than that used by Frei [1986]; the resulting paleolatitude anomaly becomes $6.3^{\circ} \pm 4.6^{\circ}$ (indicating transport of $700 \pm 500 \mathrm{~km}$ ) for the Sierra Nevada batholith. The paleomagnetic results placing the Sierra Nevada approximately $6^{\circ}$ further south during mid Cretaceous time put the Klamath-Sierra Nevada block and the Blue Mountains at similar paleolatitudes (Figure 18b). Thus correlations between the Klamath-Sierra Nevada and the Blue Mountains appear to be supported by both paleomagnetic and geological data.

\subsection{Paleogeographic Models}

[40] On the basis of the discussion above, we present three working models for the Late Cretaceous paleogeography of the Cordilleran margin of North America.

\subsubsection{Model 1: Intermontane-Blue Mountains-}

\section{Klamath-Sierra Nevada}

[41] In our preferred model, Cretaceous strata and underlying mélange rocks in the Mitchell Inlier are relatively contiguous with the larger Blue Mountains province
(Figure 1) and the Intermontane superterrane, and link the Intermontane to the Klamath-Sierra Nevada system in midCretaceous time [e.g., Silver and Smith, 1983; Mortimer, 1986; Moores, 1998]. In this model, these units were translated approximately 1200 to $1700 \mathrm{~km}$ northward during the Late Cretaceous and early Tertiary. The Sierra Nevada/Salinia arc shared $700 \mathrm{~km}$ of this translation [see also Whidden et al., 1998] with the remaining 600 to $1100 \mathrm{~km}$ representing additional post-93 Ma translation of the Blue Mountains. If the Blue Mountains were located at or near the southern end of the Sierra Nevada (perhaps near the restored position of the Salinia block [see Dickinson and Butler, 1998; Whidden et al., 1998]), a dextral fault system separating the Blue Mountains from the Sierra Nevada would be suggested. Although our proposed timing does not match, a new model suggesting that the southern Great Valley province was a transtensional/translational forearc basin [Wright, 2004] agrees well with the style of deformation that we call for here. For displacement occurring after the Blue Mountains had moved north of the Sierra Nevada, the extensive dextral fault system in western Idaho, NW Nevada, and eastern California [Wyld and Wright, 2001] is oriented favorably to have accommodated a significant portion of this displacement, although the displacement we propose is 500 to $1200 \mathrm{~km}$ greater than the estimates of Wyld and Wright [2001]. The paleomagnetic results from this study, and our interpretation of Sierra Nevada paleomagnetic data also produces estimates of translation that are significantly larger than those proposed by Umhoefer and Blakey [2005] and Wyld et al. [2005]. Our preferred model also suggests significant displacement $(1300-1800 \mathrm{~km})$ of the outboard Insular superterrane relative to the Intermontane-Blue Mountain-Klamath-Sierra block. If the Insular superterrane was located adjacent to North America (but further south), a second system of dextral faults located outboard of the Intermontane-Blue Mountain-KlamathSierra block would be called for (as proposed by Irving et al. [1996], Cowan et al. [1997], McClelland et al. [2000], and Umhoefer [2003]). Objections to this paleogeography based on the "space problem" arising from overlap between Cretaceous arcs and subduction zones (see discussions by Monger et al. [1982], Butler et al. [2001], and Dickinson [2004], for example) could be addressed by adoption of the Philippine plate-like "Cordilleria" model of Moores [1998]. In his model the Intermontane-Klamath-Sierra Nevada formed a long arc province located adjacent to the North American margin throughout much of Mesozoic time, and the Insular superterrane was part of an outboard arc system that was separated from the marginal arc by an intervening oceanic plate [see Moores, 1998, Figure 10]. The paleomagnetic data discussed above fit the Moores [1998] model remarkably well.

\subsubsection{Model 2: Ochoco and Hornbrook Basin Sliver}

[42] In this model, the Ochoco basin in the western Blue Mountains and the Hornbrook basin of the Klamath Mountains belong to a small sliver of forearc crust that experienced more northward displacement than the rest of the Blue Mountains province. In this case, our paleomagnetic results would apply only to this smaller crustal block. The remaining, more easterly parts of the Blue Mountains, Klamaths, and Sierra Nevada would be located as proposed by Wyld and Wright [2001]. The Ochoco-Hornbrook sliver 
would be located outboard and south of the Sierra Nevada arc during mid Cretaceous time, and may have been associated with the Salinian Block. An important fault boundary would be needed to separate this sliver from the central and eastern parts of the Blue Mountains, perhaps similar to faults depicted by Cowan et al. [1997] and Umhoefer [2003], but located farther east between the Mitchell Inlier and the remainder of the Blue Mountains. Northward translation of this sliver may have been associated with part of the translation of the Insular superterrane, with the Ochoco-Hornbrook basins representing portions of Baja-BC that were scraped off and left behind during terrane displacement (the "paint on the bumper" of Maxson and Tikoff [1996]). While we believe this model is possible, we presently do not favor it because (1) little deformed midCretaceous strata of the Mitchell Inlier can be traced eastward into the Suplee-Izee area where they overlap older, tectonically juxtaposed rocks of the Baker and Izee terranes [e.g., Dickinson and Thayer, 1978; Kleinhans et al., 1984]; and (2) abundant prior work has shown that the Izee, Baker, and other terranes of the Blue Mountains were amalgamated and stitched together by Late Jurassic or Early Cretaceous time [e.g., Brooks and Vallier, 1978; Dickinson and Thayer, 1978; Dickinson, 1979; White et al., 1992; Avé Lallemant, 1995]. If correct, these geological relations may rule out this model.

\subsubsection{Model 3: Greater Inclination Error}

[43] Our third model attributes the entire paleomagnetic inclination anomaly to effects of inclination error in excess of what we have detected in this study. If there was about $12^{\circ}$ of inclination error in the Gable Creek and Hudspeth Formations, the Late Cretaceous paleolatitude of the Mitchell Inlier rocks would be concordant with that expected for their present location in North America. Inclination errors of this magnitude have been proposed for similar rocks by Dickinson and Butler [1998] and Butler et al. [2001], and slightly smaller $\left(9^{\circ}\right)$ errors were proposed for the Nanaimo Group by Kim and Kodama [2004]. If correct, existing paleogeographic models that place the Blue Mountains in their present position by Early Cretaceous time [e.g., Avé Lallemant, 1995; Umhoefer, 2003; Dickinson, 2004] would be compatible with $12^{\circ}$ of inclination error. This model, or something close to it, would also be consistent with the reconstruction proposed by Wyld and Wright [2001], which calls for $\sim 400 \mathrm{~km}$ of translation of the Blue Mountains. Additional tests for such a large magnitude of inclination error would be required to support this ad hoc adjustment, because the data presented above do not support this interpretation. We also note that if there had been no northward translation of the Mitchell Inlier, the mid-Cretaceous magnetic inclination recorded in these rocks would be approximately $71^{\circ}$. According to models of inclination error [see, e.g., Tauxe and Kent, 2004] such steep inclinations are less likely to experience significant compaction shallowing. Flattening factors of $f=0.5$ to 0.6 would be needed to produce our observed mean inclination from this expected inclination; examination of model results [Jackson et al., 1991] and fabric-inclination studies [Hodych et al., 1999; Kim and Kodama, 2004] suggests that significant magnetic anisotropies $(\mathrm{P}>1.10)$ would likely be needed to achieve this degree of inclination error. Most of our magnetic fabric results have $\mathrm{P}<1.04$, so our data are not consistent with the degree of flattening needed to erase the paleomagnetic inclination anomaly we propose for these rocks. Clearly more work on detection of, and methods of correction for, significant inclination error in sedimentary rocks is needed to fully evaluate this model.

\section{Conclusions}

[44] Our paleomagnetic study has found that Albian and Cenomanian sedimentary rocks of the Gable Creek and Hudspeth Formations in the Blue Mountains, central Oregon, record the mid-Cretaceous geomagnetic field based on positive fold, baked-contact, and conglomerate tests. Examination of magnetic fabrics and the shape distribution of directional data indicates that there is little evidence for significant inclination error. We therefore conclude that the $100 \%$ untilting mean direction of $D=10.8^{\circ}, I=58.5^{\circ}, k=$ 127, $\alpha_{95}=4.1^{\circ}$, and $N=11$ for the sites south of the Mitchell fault provides the best paleomagnetic data for constraints on the paleogeography of these rocks. This result places the Mitchell Inlier at a paleolatitude of $39.2^{\circ}$ $+4.8^{\circ} /-4.3^{\circ} \mathrm{N}$ and indicates a paleolatitude anomaly of $15.9^{\circ} \pm 4.1^{\circ}$ relative to North America, giving a northward translation of $1760 \pm 460 \mathrm{~km}$, and a CW rotation of $37^{\circ} \pm$ $7.3^{\circ}$ for these rocks since circa $93 \mathrm{Ma}$. These data provide firm support for prior models invoking large $\mathrm{CW}$ rotation of the Blue Mountains during post-Cretaceous time, but indicate a need for major revision of paleogeographic models that place the Blue Mountains in their present position along the North America margin in Early Cretaceous time.

[45] We suggest that, based on prior geological correlations and similar post mid-Cretaceous translation histories, the Blue Mountains province likely correlates with the Intermontane superterrane [e.g., Mortimer, 1986], and that the Intermontane-Blue Mountains-Klamath-Sierra Nevada may have formed a large, quasi-continuous arc-forearc province during this time [e.g., Moores, 1998]. Clast compositions and paleocurrents of the Gable Creek Formation [Little, 1986; Lenegan, 2001], when corrected for the CW rotation, do not support derivation of detritus in the Ochoco basin from the nearby Western Idaho shear zone. On the basis of the similar mid-Cretaceous paleolatitudes of the Ochoco Basin $\left(39^{\circ} \mathrm{N}\right)$ and Sierra Nevada $\left(43^{\circ} \mathrm{N}\right)$, we propose that the Sierra Nevada magmatic arc and batholith may have been the source of detritus in the Gable Creek Formation.

[46] We consider other models, such as the Ochoco and Hornbrook basins occupying an anomalous forearc sliver of limited extent, or large amounts of inclination error due to compaction shallowing, to be possible but less likely. Future work is clearly needed to test these contradictory hypotheses and resolve major uncertainties concerning the tectonic architecture and evolution of the western U.S. Cordilleran system.

[47] Acknowledgments. We would like to thank many people for ongoing discussions of Blue Mountains geology and tectonics, not all of whom will agree with our conclusions. These include Paul Umhoefer, Sandra Wyld, Jim Wright, Brian Mahoney, Basil Tikoff, Ken Kodama, and Ned Brown. We also thank Associate Editor Randy Enkin and reviewers Scott Bogue and Darrel Cowan for many useful comments that improved this manuscript. Housen would like to thank Myrl Beck and Russ Burmester for many good discussions of these and other data. Funding 
from NSF grants EAR-9727032 (for the WWU Cryogenic Magnetometer) and EAR-0073888 and from the WWU Bureau for Faculty Research supported this work. Hysteresis measurements were made possible by an IRM visiting fellowship award from the University of Minnesota to Housen.

\section{References}

Ague, J. J., and M. T. Brandon (1996), Regional tilt of the Mount Stuart batholith, Washington, determined using Al-in-hornblende barometry: Implications for northward translation of Baja BC, Geol. Soc. Am. Bull., $108,471-488$.

Andronicos, C. L., L. S. Hollister, C. Davidson, and D. Chardon (1999), Kinematics and tectonic significance of transpressive structures within the Coast Plutonic Complex, British Columbia, J. Struct. Geol., 21, 229 243.

Armstrong, R. L., W. H. Taubeneck, and O. Hales (1977), Rb-Sr and K-Ar geochronometry of Mesozoic granitic rocks and their Sr isotopic composition: Oregon, Washington, and Idaho, Geol. Soc. Am. Bull., 88, $397-$ 411

Avé Lallemant, H. G. (1995), Pre-Cretaceous tectonic evolution of the Blue Mountains Province, northeastern Oregon, U.S. Geol. Surv. Prof. Pap., 1438, 271-304

Bazard, D. R., et al. (1990), Paleomagnetism of the Methow region, northcentral Washington: Structural application of paleomagnetic data in a completely deformed, variably remagnetized terrane, Can. J. Earth Sci., 27, 330-343.

Beck, M. E., Jr. (1976), Discordant paleomagnetic poles positions as evidence of regional shear in the Western Cordillera of North America, Am. J. Sci., 276, 694-712.

Beck, M. E., Jr. (1980), Paleomagnetic record of plate-margin tectonic processes along the western edge of North America, J. Geophys. Res., $85,7115-7131$.

Beck, M. E., Jr. (1999), On the shape of paleomagnetic data sets, J. Geophys. Res., 104, 25,427-25,441.

Beck, M. E., R. F. Burmester, and R. Schoonover (1981), Paleomagnetism and tectonics of the Cretaceous Mt. Stuart Batholith of Washington: Translation or tilt?, Earth Planet. Sci. Lett., 56, 336-342.

Bestland, E. A., E. Hammond, D. L. S. Blackwell, M. A. Kays, G. J. Retallack, and J. Stimac (1999), Geologic framework of the Clarno Unit, John Day Fossil Beds National Monument, central Oregon, Oreg. Geol, $61,3-19$

Bogue, S. W., and C. S. Grommé (2004), Structural correction of paleomagnetic vectors dispersed about two fold axes and application to the Duke Island (Alaska) ultramafic complex, J. Geophys. Res., 109, B11102, doi:10.1029/2004JB002989.

Bogue, S. W., D. S. Cowan, and J. I. Garver (1989), Paleomagnetic evidence for poleward transport of Upper Jurassic rocks in the Decatur terrane, San Juan Islands, Washington, J. Geophys. Res., 94, 10,41510,427 .

Brooks, H. C., and T. L. Vallier (1978), Mesozoic rocks and tectonic evolution of Oregon and western Idaho, Mesozoic paleogeography of the western United States, in Mesozoic Paleogeography of the Western United States: Society of Economic Paleontologists and Mineralogists, Pacific Section, Paleogeography Symposium, vol. 2, edited by D. G. Howell and K. A. McDougall, pp. 133-145, Soc. for Sediment. Geol., Tulsa, Okla.

Brown, E. H., and R. F. Burmester (1991), Metamorphic evidence for tilt of the Spuzzum pluton: Diminished basis for the "Baja British Columbia" concept, Tectonics, 10, 978-985.

Burchfiel, B. C., D. S. Cowan, and G. A. Davis (1992), Tectonic overview of the Cordilleran orogen in the western United States, in Geology of North America, Conterminous U.S., vol. G-3, The Cordilleran Orogen, edited by B. C. Burchfiel et al., pp. 407-479, Geol. Soc. of Am., Boulder, Colo.

Burmester, R. F., D. R. Bazard, and M. E. Beck (1990), Post-folding remagnetization that passes the fold test, Geophys. J. Int., 102, 455-463.

Burmester, R. F., M. C. Blake Jr., and D. C. Engebretson (2000), Remagnetization during Cretaceous normal superchron in eastern San Juan Islands, WA: Implications for tectonic history, Tectonophysics, 326, $73-$ 92.

Butler, R., G. Gehrels, W. McClelland, S. May, and D. Klepacki (1989), Discordant paleomagnetic poles from the Canadian coast plutonic complex: Regional tilt rather than large scale displacement?, Geology, 17, 691-694.

Butler, R. F., G. E. Gehrels, and K. Kodama (2001), A moderate translation alternative to the Baja British Columbia hypothesis, GSA Today, 11, 4-10. Butler, R. F., G. E. Gehrels, S. E. Baldwin, and C. Davidson (2002), Paleomagnetism and geochronology of the Ecstall pluton in the Coast Mountains orogen of British Columbia: Local deformation rather than large-scale transport, J. Geophys. Res., 107(B1), 2009, doi:10.1029/ 2001JB000270

Coney, J., D. L. Jones, and J. W. H. Monger (1980), Cordilleran suspect terranes, Nature, 288, 329-333.

Cowan, D. S., M. T. Brandon, and J. I. Garver (1997), Geologic tests of hypotheses for large coastwise displacements: A critique illustrated by the Baja British Columbia controversy, Am. J. Sci., 297, 117-173.

Criss, R. E., and R. J. Fleck (1987), Petrogenesis, geochronology, and hydrothermal systems of the northern Idaho batholith and adjacent areas based on ${ }^{18} \mathrm{O} /{ }^{16} \mathrm{O}, \mathrm{D} / \mathrm{H} /{ }^{87} \mathrm{Sr} /{ }^{86} \mathrm{Sr}, \mathrm{A}-\mathrm{Ar}$, and ${ }^{40} \mathrm{Ar}-{ }^{39} \mathrm{Ar}$ studies, in Geology of the Blue Mountains Region of Oregon, Idaho, and Washington, edited by T. L. Vallier and H. C. Brooks, U.S. Geol. Surv. Prof. Pap., 1436, $171-196$.

Day, R., M. Fuller, and V. A. Schmidt (1977), Hysteresis properties of titanomagnetites: Grain-size and compositional dependence, Phys. Earth Planet. Inter., 13, 260-267.

Demarest, H. H. (1983), Error analysis of the determination of tectonic rotation from paleomagnetic data, J. Geophys. Res., 88, 4321-4328.

Dickinson, W. R. (1979), Mesozoic forearc basin in central Oregon, Geology, 7, 166-170.

Dickinson, W. R. (2002), The Basin and Range province as a composite extensional domain, Int. Geol. Rev., 44, 1-38.

Dickinson, W. R. (2004), Evolution of the North American Cordillera, Ann. Rev. Earth Planet. Sci., 32, 13-45.

Dickinson, W. R., and R. F. Butler (1998), Coastal and Baja California paleomagnetism revisited, Geol. Soc. Am. Bull., 110, 1268-1280.

Dickinson, W. R., and T. Thayer (1978), Paleogeographic and paleotectonic implications of Mesozoic stratigraphy and structure in the John Day inlier of central Oregon, in Mesozoic Paleogeography of the Western United States: Society of Economic Paleontologists and Mineralogists, Pacific Section, Paleogeography Symposium, vol. 2, edited by D. G. Howell and K. A. McDougall, pp. 147-161, Soc. for Sediment. Geol., Tulsa, Okla. Dunlop, D. J. (2002), Theory and application of the Day plot $\left(M_{r s} / M_{s}\right.$ versus $\left.H_{c r} / H_{c}\right)$ : 2. Application to data for rocks, sediments, and soils, J. Geophys. Res., 107(B3), 2057, doi:10.1029/2001JB000487.

Dupont-Nivet, G., Z. Guo, R. Butler, and C. Jia (2002), Discordant paleomagnetic direction in Miocene rocks from the central Tarim Basin: Evidence for local deformation and inclination shallowing, Earth Planet. Sci. Lett., 199, 473-482.

Engebretson, D. C., A. Cox, and R. G. Gordon (1985), Relative motion between oceanic and continental plates in the Pacific Basin, Spec. Pap. Geol. Soc. Am., 206, 1-59.

England, P. C., and R. E. Wells (1991), Neogene rotations and continuum deformation of the Pacific Northwest convergent margin, Geology, 19, 978-981

Enkin, R. J. (2003), The direction-correction tilt test: An all-purpose tilt/ fold test for paleomagnetic studies, Earth Planet. Sci. Lett., 212, 151166.

Enkin, R. J., and G. S. Watson (1996), Statistical analysis of palaeomagnetic inclination data, Geophys. J. Int., 126, 495-504.

Enkin, R. J., J. Baker, and P. S. Mustard (2001), Paleomagnetism of the Upper Cretaceous Nanaimo Group, southwestern Canadian Cordillera, Can. J. Earth Sci., 38, 1403-1422.

Enkin, R. J., J. B. Mahoney, J. Baker, M. Keissling, and R. A. Haugerud (2002), Syntectonic remagnetization in the southern Methow block: Resolving large displacements in the southern Canadian Cordillera, Tectonics, 2l(4), 1036, doi:10.1029/2001TC001294.

Enkin, R. J., J. B. Mahoney, J. Baker, J. Riesterer, and M. L. Haskin (2003), Deciphering shallow paleomagnetic inclinations: 2. Implications from Late Cretaceous strata overlapping the Insular/Intermontane Superterrane boundary in the southern Canadian Cordillera, J. Geophys. Res., 108(B4), 2186, doi:10.1029/2002JB001983.

Fisher, R. A. (1953), Dispersion on a sphere, Proc. R. Soc London, Ser. A., 217, 295-305.

Fleck, R. J., and R. E. Criss (1985), Strontium and oxygen isotopic variations in Mesozoic and Tertiary plutons of central Idaho, Contrib. Mineral. Petrol., 90, 291-308.

Follo, M. F. (1992), Conglomerates as clues to the sedimentary and tectonic evolution of a suspect terrane: Wallowa Mountains, Oregon, Geol. Soc. Am. Bull., 104, 1561-1576.

Fossen, H., and B. Tikoff (1998), Extended models of transpression and transtension, and application to tectonic settings, in Continental Transpressional and Transtensional Tectonics, edited by R. E. Holdsworth, R. A. Strachan, and J. F. Dewey, Geol. Soc. Spec. Publ., 135, 15-33.

Frei, L. S. (1986), Additional paleomagnetic results from the Sierra Nevada: Further constraints on Basin and Range extension and northward displacement in the western United States, Geol. Soc. Am. Bull., 97, 840-849.

Frei, L. S., J. Magill, and A. Cox (1984), Paleomagnetic results from the central Sierra Nevada: Constraints on reconstruction of the western United States, Tectonics, 3, 157-177. 
Gilder, S., Y. Chen, and S. Sen (2001), Oligo-Miocene magnetostratigraphy and rock magnetism of the Xishuigou section, Subei (Gansu Province, western China) and implications for shallow inclinations in central Asia, J. Geophys. Res., 106, 30,505-30,521.

Gilder, S., Y. Chen, J. Cogné, X. Tan, V. Courtillot, D. Sun, and Y. Li (2003), Paleomagnetism of Upper Jurassic to Lower Cretaceous volcanic and sedimentary rocks from the western Tarim Basin and implications for inclination shallowing and absolute dating of the M-O (ISEA?) chron, Earth Planet. Sci. Lett., 206, 587-600.

Grommé, C. S., M. E. Beck Jr., and D. C. Engebretson (1986), Paleomagnetism of the Tertiary Clarno Formation of central Oregon and its significance for the tectonic history of the Pacific Northwest, J. Geophys. Res., 91, 14,089-14,103.

Hacker, B. R., and S. M. Peacock (1990), Comparison of the Central Metamorphic Belt and Trinity terrane of the Klamath Mountains with the Feather River terrane of the Sierra Nevada, in Paleozoic and EARLY MESOZOIC Paleogeographic Relations: Sierra Nevada, Klamath Mountains, and Related Terranes, edited by D. S. Harwood and M. M. Miller, Spec. Pap. Geol. Soc. Am., 255, 75-92.

Hacker, B. R., M. M. Donato, C. G. Barnes, M. O. McWilliams, and W. G. Ernst (1995), Timescales of orogeny: Jurassic construction of the Klamath Mountains, Tectonics, 14, 677-703.

Hamilton, W., and W. B. Myers (1966), Cenozoic tectonics of the western United States, Rev. Geophys., 4, 509-549.

Haskin, M. L., R. J. Enkin, J. B. Mahoney, P. S. Mustard, and J. Baker (2003), Deciphering shallow paleomagnetic inclinations: 1. Implications from correlation of Albian volcanic rocks along the Insular/Intermontane Superterrane boundary in the southern Canadian Cordillera, J. Geophys. Res., 108(B4), 2185, doi:10.1029/2002JB001982.

Hillhouse, J. W., and C. S. Grommé (1984), Northward displacement and accretion of Wrangellia: New paleomagnetic evidence from Alaska, J. Geophys. Res., 89, 4461-4477.

Hillhouse, J. W., C. S. Grommé, and T. L. Vallier (1982), Paleomagnetism and Mesozoic tectonics of the Seven Devils volcanic arc in northeastern Oregon, J. Geophys. Res., 87, 3777-3794.

Hodych, J., S. Bijaksana, and R. Paetzold (1999), Using magnetic anisotropy to correct for paleomagnetic inclination shallowing in some magnetite-bearing deep-sea turbidites and limestones, Tectonophysics, 307, $191-205$

Hollister, L. S., R. B. Hargraves, T. S. James, and R. Renne (2004), The paleomagnetic effects of reheating the Ecstall pluton, British Columbia, Earth Planet. Sci. Lett., 221, 397-407.

Housen, B. A., and M. E. Beck Jr. (1999), Testing terrane transport: An inclusive approach to the Baja B.C. controversy, Geology, 27, 11431146.

Housen, B. A., et al. (2003), Paleomagnetism of the Mount Stuart Batholith revisited again: What has been learned since 1972?, Am. Sci, J., 303 , $263-299$.

Ingersoll, R., and R. A. Schweickert (1986), A plate-tectonic model for Late Jurassic ophiolite genesis, Nevadan orogeny and forearc initiation, northern California, Tectonics, 5, 901-912.

Irving, E., and D. A. Archibald (1990), Bathozonal tilt corrections to paleomagnetic data from mid-Cretaceous plutonic rocks: Examples from the Omineca Belt, British Columbia, J. Geophys. Res., 95, 4579-4585.

Irving, E., D. J. Thorkelson, M. Wheadon, and R. J. Enkin (1995), Paleomagnetism of the Spences Bridge Group and northward displacements of the Intermontane Belt, British Columbia: A second look, J. Geophys. Res., 100, 6057-6071.

Irving, E., P. J. Wynne, D. J. Thorkelson, and P. Schiarizza (1996), Large (1000 to $4000 \mathrm{~km}$ ) northward movements of tectonic domains in the northern Cordillera, 83-45 Ma, J. Geophys. Res., 101, 17,901-17,916.

Irwin, W. P. (2003), Correlation of the Klamath Mountains and Sierra Nevada, U.S. Geol. Surv. Open File Rep., 02-490, 2 sheets.

Irwin, W. P., and E. A. Mankinen (1998), Rotational and accretionary evolution of the Klamath Mountains, California and Oregon, from Devonian to present time, U.S. Geol. Surv. Open File Rep., 98-114, 114 pp

Jackson, M. J., S. K. Banerjee, R. Lu, and W. Gruber (1991), Detrital remanence, inclination errors, and anhysteretic remanence anisotropy: Quantitative model and experimental results, Geophys. J. Int., 104, 95- 103 .

Johnston, S. T., P. J. Wynne, D. Francis, C. J. R. Hart, R. J. Enkin, and D. C. Engebretson (1996), Yellowstone in the Yukon: The Late Cretaceous Carmacks Group, Geology, 24, 997-1000.

Jones, D. L., N. J. Silberling, and J. W. Hillhouse (1977), Wrangellia, a displaced terrane in northwestern North America, Can. J. Earth Sci., 14, $2565-2577$.

Kim, B.-Y., and K. P. Kodama (2004), A compaction correction for the paleomagnetism of the Nanaimo Group sedimentary rocks: Implications for the Baja British Columbia hypothesis, J. Geophys. Res., 109, B02102, doi:10.1029/2003JB002696.
King, R. F. (1955), The remanent magnetism of artificially deposited sediments, Mon. Not. R. Astron. Soc., Geophys. Suppl., 7, 115-134.

Kirschvink, J. L. (1980), The least-squares line and plane and the analysis of paleomagnetic data, Geophys. J. R. Astron. Soc., 62, 699-718.

Kleinhans, L. C., E. A. Barcells-Baldwin, and R. E. Jones (1984), A paleogeographic reinterpretation of some middle Cretaceous units, northcentral Oregon: Evidence for a submarine turbidite system, in ed., Geology of the Upper Cretaceous Hornbrook Formation, Oregon and California, Fieldtrip Guidebk., vol. 42, edited by T. H. Nilsen, pp. 239257, Soc. for Sediment. Geol., Tulsa, Okla.

Kodama, K. P. (1997), A successful rock magnetic technique for correcting paleomagnetic inclination shallowing: Case study of the Nacimiento Formation, New Mexico, J. Geophys. Res., 102, 5193-5205.

Krijgsman, W., and L. Tauxe (2004), Shallow bias in Mediterranean paleomagnetic directions caused by inclination error, Earth Planet Sci. Lett., $222,685-695$.

Lenegan, R. J. (2001), Middle Cretaceous sedimentation and tectonics of the Mitchell inlier, Wheeler County, central Oregon, M.S. thesis, 125 pp., Univ. of Oreg., Eugene.

Little, S. W. (1986), Stratigraphy, petrology, and provenance of the Cretaceous Gable Creek Formation, Wheeler County, Oregon, M.S. thesis, 133 pp., Oreg. State Univ., Corvallis.

Lund, K., and L. W. Snee (1988), Metamorphism, structural development, and age of the continent-island arc juncture in west-central Idaho, in $\mathrm{Me}$ tamorphism and Crustal Evolution of the Western United States, edited by W. G. Ernst, pp. 297-331, Prentice-Hall, Upper Saddle River, N. J.

Mahoney, J. B., P. S. Mustard, J. W. Haggart, R. M. Friedman, C. M. Fanning, and J. McNicoll (1999), Archean zircons in Cretaceous strata of the western Canadian Cordillera: The "Baja B.C." hypothesis fails a "crucial test," Geology, 27, 195-198.

Manduca, C. A., L. T. Silver, and H. Taylor (1992), ${ }^{87} \mathrm{Sr} /{ }^{86} \mathrm{Sr}$ and ${ }^{18} \mathrm{O} /{ }^{16} \mathrm{O}$ isotopic systematics and geochemistry of granitoid plutons across a steeply dipping boundary between contrasting lithospheric blocks in western Idaho, Contrib. Mineral. Petrol., 109, 355-372.

Manduca, C. A., M. A. Kuntz, and L. T. Silver (1993), Emplacement and deformation history of the western margin of the Idaho Batholith near McCall, Idaho: Influence of a major terrane boundary, Geol. Soc. Am. Bull., 105, 749-765.

Mankinen, E. A., and W. P. Irwin (1982), Paleomagnetic study of some Cretaceous and Tertiary sedimentary rocks of the Klamath Mountains province, California, Geology, 10, 82-87.

Maxson, J., and B. Tikoff (1996), Hit-and-run collision model for the Laramide orogeny, western United States, Geology, 24, 672-698.

McClelland, W. C., B. Tikoff, and C. A. Manduca (2000), Two-phase evolution of accretionary margins: Examples from the North American Cordillera, Tectonophysics, 326, 37-55.

McFadden, L., and A. B. Reid (1982), Analysis of paleomagnetic inclination data, Geophys. J. R. Astron. Soc., 69, 307-319.

McKnight, B. K. (1964), A stratigraphic study of the marine Cretaceous rocks near Mitchell, Oregon, M.S. thesis, 89 pp., Oreg. State Univ., Corvallis.

Miller, I. M., L. J. Hickey, and M. T. Brandon (2003), A paleobotanical method for restoring far-travelled terranes, Geol. Soc. Am. Abstr. Programs, 35, 113 .

Monger, J. W. H., R. A. Price, and D. J. Templeman-Kluit (1982), Tectonic accretion and the origin of the two major metamorphic and plutonic welts in the Canadian Cordillera, Geology, 10, 70-75.

Monger, J. W. H., P. van der Heyden, J. M. Journeay, C. A. Evenchick, and J. B. Mahoney (1994), Jurassic-Cretaceous basins along the Canadian Coast Belt: Their bearing on pre-mid-Cretaceous sinistral displacements, Geology, 22, 175-178.

Moores, E. M. (1998), Ophiolites, the Sierra Nevada "Cordilleria," and orogeny along the Pacific and Caribbean margins of North and South America, Int. Geol. Rev., 40, 40-54.

Mortimer, N. (1986), Late Triassic, arc-related, potassic igneous rocks in the North American Cordillera, Geology, 14, 1035-1038.

Mustard, P. S., R. R. Parrish, and V. McNicoll (1995), Provenance of the Upper Cretaceous Nanaimo Group, British Columbia: Evidence from U$\mathrm{Pb}$ analyses of detrital zircons, in Stratigraphic Development in Foreland Basins, edited by S. L. Dorobek and G. M. Ross, Spec. Publ. SEPM Soc. Sediment. Geol., 52, 112-127.

Nilsen, T. H. (1986), Cretaceous paleogeography of western North America, in Abbott, L., ed., Cretaceous Stratigraphy of Western North America, pp. 1-39, Soc. for Sediment. Geol., Tulsa, Okla.

Oles, K. F., and H. E. Enlows (1971), Bedrock geology of the Mitchell quadrangle, Wheeler County, Oregon, Bull. Oreg. Dep. Geol. Miner. Ind., $72,62 \mathrm{pp}$.

Price, R. A., and D. M. Charmichael (1986), Geometric test for Late Cretaceous-Paleogene intracontinental transform faulting in the Canadian Cordillera, Geology, 14, 468-471. 
Saleeby, J. B. (1990), Progress in tectonic and petrogenetic studies in an exposed cross-section of young (circa $100 \mathrm{Ma}$ ) continental crust, southern Sierra Nevada, California, in Exposed Cross Sections of the Continental Crust, edited by M. H. Salisbury, pp. 137-158, Springer, New York.

Sarewitz, D. (1983), Seven Devils terrane: Is it really a piece of Wrangellia?, Geology, 11, 634-637.

Schott, R. C., and C. M. Johnson (2001), Garnet-bearing trondhjemite and other conglomerate clasts from the Gualala Basin, California: Sedimentary record of the missing western portion of the Salinian magmatic arc?, Geol. Soc. Am. Bull., 113, 870-880.

Schott, R. C., C. M. Johnson, and J. R. O-Neil (2004), Late Cretaceous tectonic history of the Sierra-Salinia-Mojave arc as recorded in conglomerates of the Upper Cretaceous and Paleocene Gualala Formation, northern California, J. Geophys. Res., 109, B02204, doi:10.1029/ 2003JB002845.

Selverstone, J., B. Wernicke, and E. A. Aliberti (1992), Intracontinental subduction and hinged unroofing along the Salmon River suture zone, west central Idaho, Tectonics, 11, 124-144.

Silberling, N. J., D. L. Jones, M. C. Blake Jr., and D. G. Howell (1984), Lithotectonic terrane map of the western conterminous United States, U.S. Geol. Surv. Open File Rep., 84-0523, C1-C43.

Silver, E. A., and R. B. Smith (1983), Comparison of terrane accretion in modern southeast Asia and the Mesozoic North American Cordillera, Geology, 11, 198-202.

Stamatakos, J. A., J. M. Trop, and K. D. Ridgway (2001), Late Cretaceous paleogeography of the MacColl Ridge Formation, southern Alaska, revisited, Geology, 29, 947-950.

Sun, W. W., and K. P. Kodama (1992), Magnetic anisotropy, scanning electron microscopy, and X-ray pole figure goniometry study of inclination shallowing in a compacting clay-rich sediment, J. Geophys. Res., 97, $19,599-19,615$

Tarling, D. H., and F. Hrouda (1993), The Magnetic Anisotropy of Rocks, 217 pp., CRC Press, Boca, Raton, Fla.

Tauxe, L. (1993), Sedimentary records of relative paleointensity of the geomagnetic field: Theory and practice, Rev. Geophys., 31, 319-354.

Tauxe, L. (1998), Paleomagnetic Principles and Practice, 299 pp., Springer, New York.

Tauxe, L., and D. V. Kent (2004), A simplified statistical model for the geomagnetic field and the detection of shallow bias in paleomagnetic inclinations: Was the ancient magnetic field dipolar?, in Timescales of the Paleomagnetic Field, Geophys. Monogr. Ser., vol. 145, edited by J. E. T. Channell et al., pp. 101-115, AGU, Washington, D. C.

Tauxe, L., and G. S. Watson (1994), The fold test: An eigen analysis approach, Earth Planet. Sci. Lett., 122, 331-341.

Thompson, G. G., J. R. Yett, and K. E. Green (1984), Subsurface stratigraphy of the Ochoco Basin, Oregon, Oil Gas Invest. Oreg. Dep. Geol. Miner. Ind., 8, $18 \mathrm{pp}$.

Umhoefer, P. J. (2003), A speculative model on the North America Cordillera in the Early Cretaceous: Tectonic escape related to arc collision of the Guerrero terrane and a change in North America plate motion, Spec. Pap. Geol. Soc. Am., 374, 117-134.

Umhoefer, P. J., and R. C. Blakey (2005), Moderate (1600 km) northward translation of Baja British Columbia from southern California: An attempt at reconciliation of paleomagnetism and geology, in Paleogeography of Western North America: Evidence for and Against Large-Scale Displacements, edited by J. W. Haggart, R. J. Enkin, and J. W. H. Monger, Geol. Assoc. Can. Spec. Pap., in press.

Watson, G. S., and R. J. Enkin (1993), The fold test in paleomagnetism as a parameter estimation problem, Geophys. Res. Lett., 20, 2135-2137.

Wernicke, B., and D. W. Klepacki (1988), Escape hypothesis for the Stikine Block, Geology, 16, 461-464.

Whidden, K. J., S. P. Lund, D. J. Bottjer, D. Champion, and D. G. Howell (1998), Paleomagnetic evidence the central block of Salinia (California) is not a far-traveled terrane, Tectonics, 17, 329-343.

White, J. D. L., D. L. White, T. L. Vallier, G. D. Stanley Jr., and S. R. Ash (1992), Middle Jurassic strata link Wallowa, Olds Ferry, and Izee terranes in the accreted Blue Mountains island arc, northeastern Oregon, Geology, $20,729-732$.

Wilkinson, W. D., and K. F. Oles (1968), Stratigraphy and paleoenvironments of Cretaceous rocks, Mitchell Quadrangle, Oregon, AAPG Bull., $52,129-161$.

Wilson, D., and A. Cox (1980), Paleomagnetic evidence for tectonic rotation of Jurassic plutons in Blue Mountains, eastern Oregon, J. Geophys. Res., 85, 3681-3689.

Wright, J. E. (2004), Did the Great Valley Group accumulate in a translational rather than stationary fore arc basin?, Geol. Soc. Am. Abstr. Programs, 36, 120.

Wyld, S. J., and J. E. Wright (2001), New evidence for Cretaceous strikeslip faulting in the United States Cordillera and implications for terranedisplacement, deformation patterns, and plutonism, Am. J. Sci., 301, $150-181$.

Wyld, S. J., P. J. Umhoefer, and J. E. Wright (2005), Reconstructing northern Cordilleran terranes along known Cretaceous and Cenozoic strike-slip faults: Implications for the Baja B.C. hypothesis and other models, in Paleogeography of Western North America: Evidence for and Against Large-Scale Displacements, edited by J. W. Haggart, R. J. Enkin, and J. W. H. Monger, Geol. Assoc. Can. Spec. Pap., in press.

Wynne, P. J., E. Irving, J. A. Maxson, and K. L. Kleinspehn (1995), Paleomagnetism of the Upper Cretaceous strata of Mount Tatlow: Evidence for $3000 \mathrm{~km}$ of northward displacement of the eastern Coast Belt, British Columbia, J. Geophys. Res., 100, 6073-6091.

Wynne, P. J., R. J. Enkin, J. Baker, S. T. Johnston, and C. J. R. Hart (1998) The big flush: Paleomagnetic signature of a 70 Ma regional hydrothermal event in displaced rocks of the northern Canadian Cordillera, Can. J. Earth Sci., 35, 657-671.

Yole, R. W., and E. Irving (1980), Displacement of Vancouver Island: Paleomagnetic evidence from the Karmutsen Formation, Can. J. Earth Sci., 17, 1210-1288.

R. J. Dorsey, Department of Geological Sciences, University of Oregon, Eugene, OR 97403, USA.

B. A. Housen, Geology Department, Western Washington University, Bellingham, WA 98225, USA. (bernieh@cc.wwu.edu) 